\title{
START
}

Short Term Assistance For Rehabilitation Team AFGHAN CONSILLTANTS

Prewar School Buildings

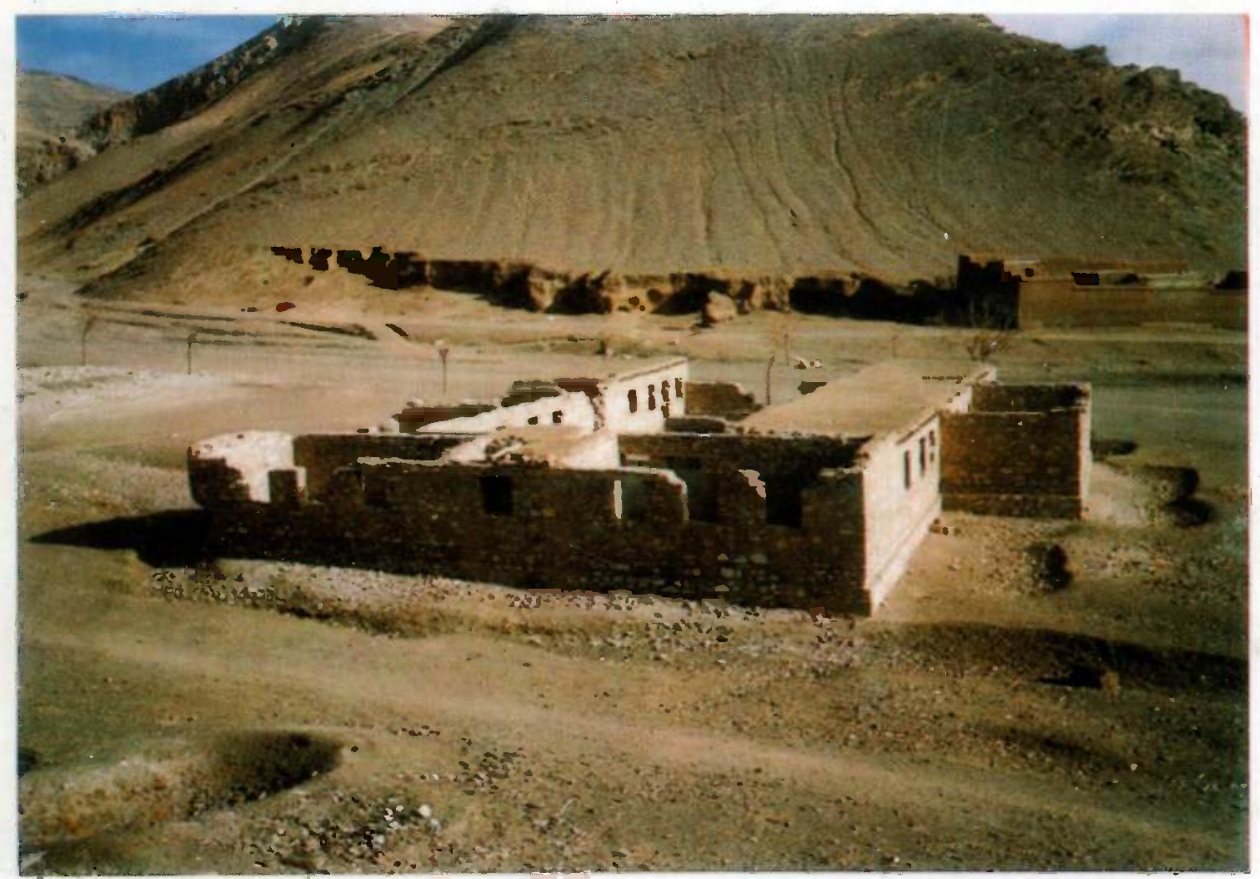

An inventory Eurvey in Wardak prouince

January 1790 







\section{SCHOOL BUILDING}

Inventory Survey of Pre-war School buildings Said Abad \& Chack districts Wardak, Afghanistan.

\section{BACKGROUND :}

Education is getting to be one of the basic and much important sectors to work in the rehabilitation process inside Afghanistan. As it is envisioned the environment for promotion of this sector is also now getting favorable. More of the Afghans living inside realize the need for education and show their readiness for support in this regard. Today there are many schools inside Afghanistan that are funded by NGO's and Mujahideen administrations. Afghanistan Education Committee (AEC) funds about 480 of these schools that have been running to a satisfactory degree. But most of such education is going on under trees, in the caves, in mosques and sometimes in the open air on an autumn day. There are almost no proper school building today as most of them are destroyed, deserted and abandoned due to the 10 years of war.

The need for survey of the pre-war school buildings inside the liberated areas was identified by A.W. Najimi, architect and planner Ph.D, of the Afghanistan Education committee, as the basis for planning and project design for rehabilitation of the educational infrastructure.

As the school education would be, and should be, a top priority in the future Afghanistan and as the rehabilitation process is already started up in other sectors, it is time to look for possibilities to rehabilitate the educational infrastructure and the required buildings. Therefore, it is essential to conduct inventory surveys to know the exact condition of the prewar school buildings first. And to see how much efforts it would need to rehabilitate the semi-destroyed buildings, before one should decide to plan construction of new school buildings.

\section{OBJECTIVES :}

The objective was to conduct a pilot project, an inventory survey of the remaining prewar school buildings in two districts of Wardak province. 


\section{STRATEGY :}

As a pilot project a survey was launched in the two districts of Said Abad and Chack in Wardak province. Schools founded by AEC of Swedish Committee has been running well in this area that made an excellent site to start such a survey. START was contracted. START assigned one architect, 5 engineers and surveyors, having their origin from different places in Afghanistan, and AEC provided payments for a month salaries, perdiem and limited travel expenses of the team. The team modestly traveled into Afghanistan by local route transportation. And in many streches they had to go on foot.

The team left for Afghanistan in late November 1989 and through their one month stay in the two mentioned districts they visited, measured and photographed 22 schools of highschool, scondry and primary levels. Mast of the school buildings are badly damaged due to deliberate distraction by Kabul troops and their air raids and bombings. Some buildings along the highway have been razed by bulldozers and the remaining has no roofing, door, and windows intact. The timbers from roof are also disappeared.

Among the 22 surveyed sites, only at two places the team was not allowed to document the damaged school buildings as the inhabitants did not recommend rehabilitation of these buildings and preferred school building at other sites where the children would not disturb village life and the cultivated fields. At other places the inhabitants, the commanders and local political representative showed great interest for the rehabilitation of education in proper school buildings and also showed readiness for support and work.

The environment in these two districts of Wardak are both politically and physically in favor of school building activities. The province is accessible from Terimangal and the needed external items could easily be transported to the province.

Local building material are found, only timber might be in shortage and should be supplied from other places. Labor are also easily recruited and they know the local building traditions, but would better be supervised with some expertise for improved results.

The following are a brief documentation of the school buildings surveyed, only to give a general account in this context. 
.

$4 x^{2}$

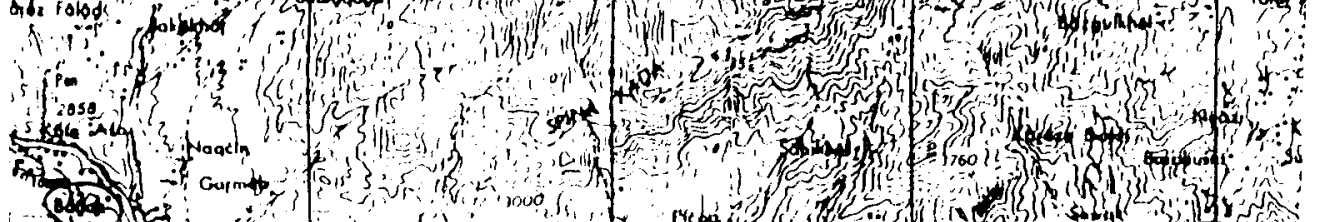

-

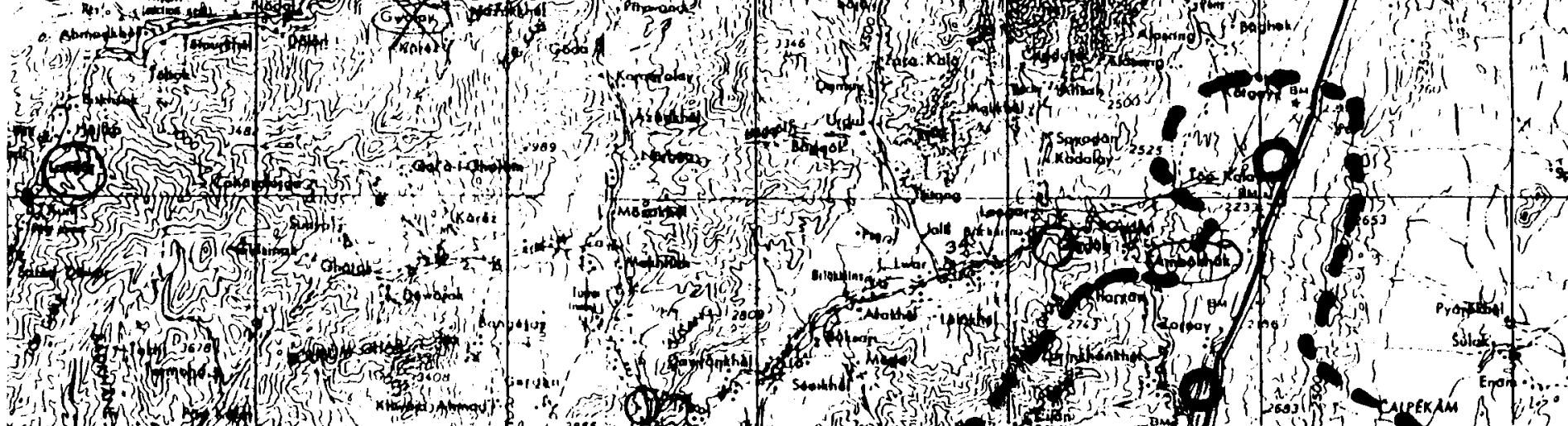

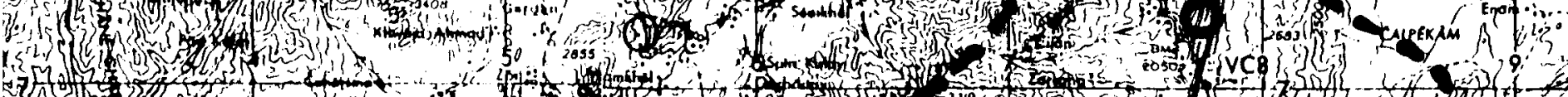

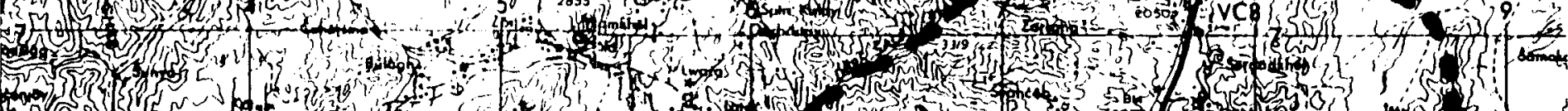
Lon 30 ond (s)

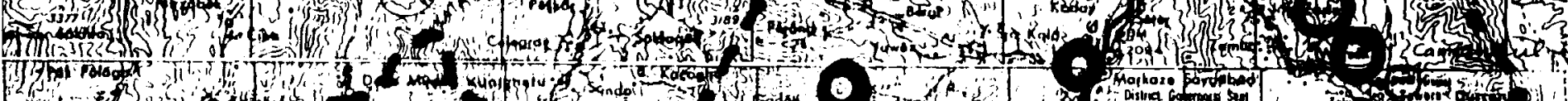



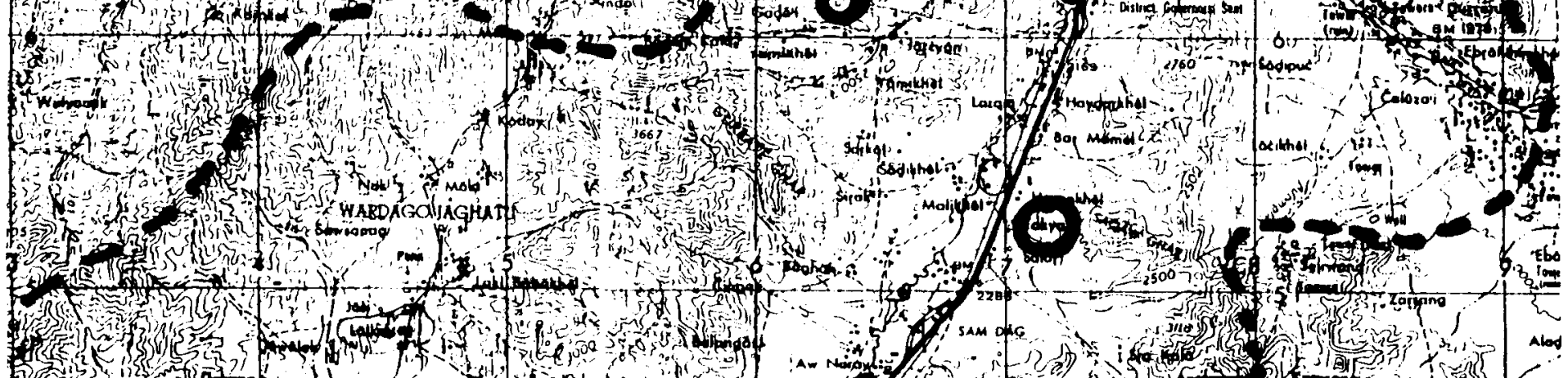
(3) (2) potog

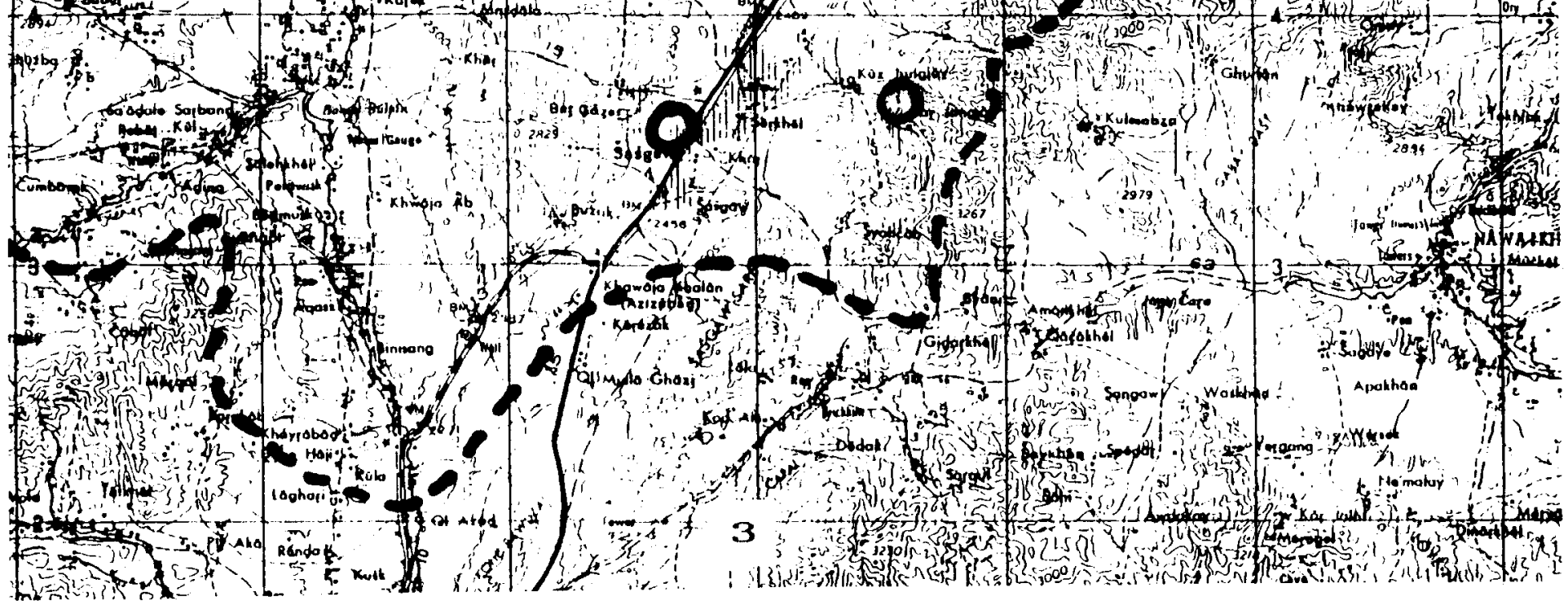




\begin{tabular}{|c|c|c|c|c|c|c|c|c|c|c|c|c|c|c|c|}
\hline \multirow[b]{3}{*}{ No. } & \multicolumn{4}{|l|}{ Schools } & \multirow{3}{*}{ 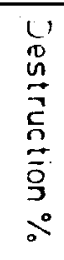 } & \multicolumn{9}{|c|}{ Type of construction materials } & \multirow{3}{*}{$\begin{array}{l}D \\
0 \\
3 \\
0 \\
0 \\
\overline{1} \\
n\end{array}$} \\
\hline & \multirow[b]{2}{*}{ Name } & \multirow[t]{2}{*}{ 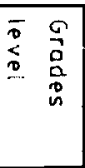 } & \multirow{2}{*}{ 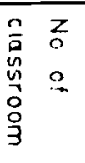 } & \multirow[t]{2}{*}{ 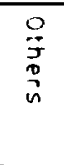 } & & \multirow[t]{2}{*}{$\begin{array}{l}x \\
0 \\
0 \\
0\end{array}$} & \multirow[t]{2}{*}{$\underset{D}{\Sigma}$} & \multirow[t]{2}{*}{$\frac{\pi}{\circ}$} & \multicolumn{3}{|c|}{ Size of windows } & \multicolumn{3}{|c|}{ Size of doors } & \\
\hline & & & & & & & & & $w_{\mathrm{cm}}$ & $\mathrm{H}_{\mathrm{an}}$ & No. & $w_{\mathrm{om}}$ & $\mathrm{Hon}_{\mathrm{ol}}$ & No. & \\
\hline 1 & Shash Qcika Secondary School & 9 & 10 & 3 & no & Not & musd & mud & 200 & 180 & 1,6 & 90 & $2 \mathrm{CO}$ & 13 & \\
\hline 2 & " & & & & & $=$ & . & $\because$ & 150 & 170 & 2 & & . & & \\
\hline 3 & Jang Jay Frimary School & 3 & 3 & 1 & 80 & : & '. & . & 150 & 170 & 7 & 100 & 200 & 3 & \\
\hline 4 & " & & & & & & $:$ & $\because$ & 100 & 60 & 1 & 90 & 200 & 1 & \\
\hline 5. & Lora Primary School & 3 & 1 & 3 & 100 & : &. & ", & 150 & 170 & 12 & 100 & 120 & 7 & \\
\hline 6 & Takya Seccindrity School & 9 & 12 & 10 & 100 & 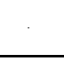 & 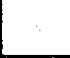 & " & 200 & 170 & 42 & 250 & 250 & 1 & \\
\hline 7 & : & & & & & : & & . & & & & 100 & 250 & 18 & \\
\hline 8 & $\therefore$ & & & & & $:$ & & . & & & & 150 & 250 & 2 & \\
\hline 9 & Hezral Gul Mosquh & & & 2 & 50 & - & 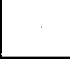 & . & $: 00$ & 100 & 2 & 106 & 200 & 2 & \\
\hline 10 & $\therefore$ & & & & &. & $"$ & " & 150 & 100 & 1 & &. & . & \\
\hline 11 & Sayd abad high school & 12 & 24 & 10 & 80 & $"$ &. &. & 200 & 180 & 22 & 100 & 200 & 29 & \\
\hline 12 &. & & & . & &. & . & .. & 150 & 170 & 9 & 150 & 250 & 4 & \\
\hline 13 & ". & & & & & " & " & " & 100 & 60 & 4 & & & . & \\
\hline
\end{tabular}

\section{SHELTER FORM}

Province: Wardak Distric!: Jagliatu

\section{START}

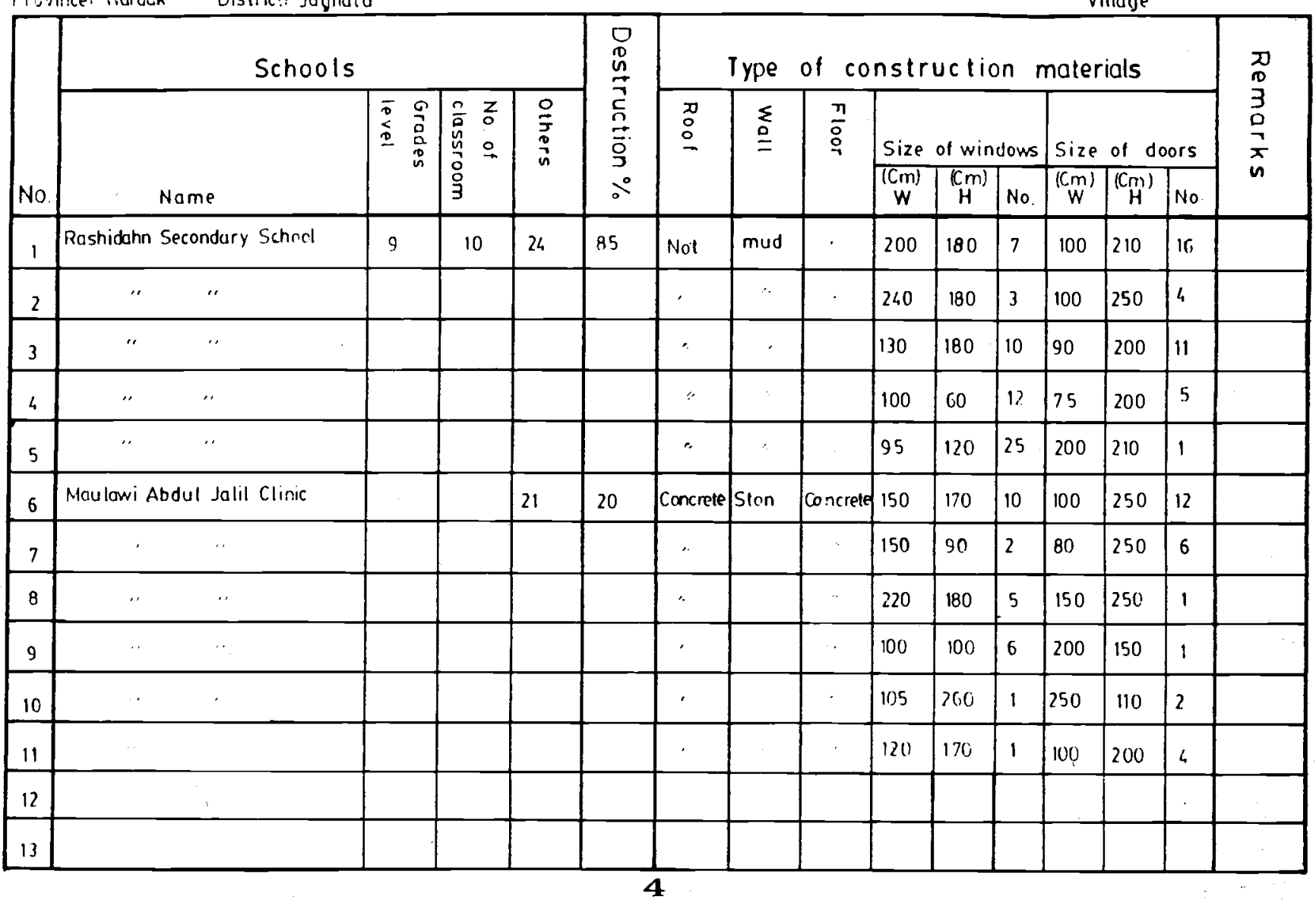

Shorl lerm assistance for rehabilitation team 
CHART OF CONSIIRUCIIION AND LABOUR WAGES

\begin{tabular}{|c|c|c|c|c|c|c|c|c|c|c|c|c|c|c|c|c|c|c|c|}
\hline \multirow[b]{2}{*}{ i } & \multicolumn{3}{|c|}{ - Surveyed Area } & \multicolumn{5}{|c|}{ Cist of miterkilsinitind } & \multirow{2}{*}{ 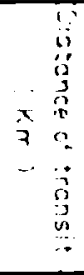 } & \multirow{2}{*}{ 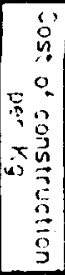 } & \multicolumn{3}{|c|}{$\begin{array}{r}\text { Cistof folinl } \\
\text { iten:Is(An) }\end{array}$} & \multicolumn{3}{|c|}{ inkige per diy } & \multirow{2}{*}{ 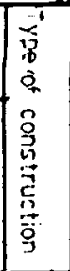 } & \multirow{2}{*}{ 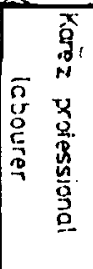 } & \multirow{2}{*}{ remarks } \\
\hline & Villong: & District & Frnvince & 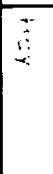 & $\because$ & \begin{tabular}{|l|l} 
\\
0 \\
0 \\
0 \\
0 \\
0
\end{tabular} & \begin{tabular}{|c|} 
\\
0 \\
0 \\
$\vdots$ \\
2
\end{tabular} & $\begin{array}{l}10 \\
6 \\
5 \\
7\end{array}$ & & & \begin{tabular}{|l}
0 \\
\\
8 \\
9
\end{tabular} & $\begin{array}{l}\vdots \\
\vdots \\
\alpha \\
0 \\
\vdots\end{array}$ & 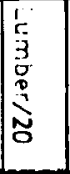 & 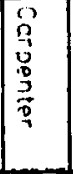 & $\begin{array}{l}3 \\
0 \\
0 \\
0 \\
0 \\
3\end{array}$ & \begin{tabular}{|l|} 
\\
0 \\
0 \\
0 \\
0 \\
$\vdots$ \\
1 \\
\end{tabular} & & & \\
\hline 1 & Rasheedahn & Jaghatu & Wardak & 35 & 6000 & 7000 & 7000 & 8000 & 6 & $\cdot$ & 100001 & 11000 & 40000 & 2000 & 1500 & 1000 & Mud & & \\
\hline 2 & Da-e-Kalan & $1 /$ & $/ /$ & .1 & $1 /$ & $1 /$ & $/ 1$ & 7000 & 2 & . & 11000 & $1 /$ & 50000 & $1 /$ & 2000 & 1100 & $/ /$ & & \\
\hline 3 & A Mohieudin & // & /1 & $/ 1$ & 5500 & 6000 & 6500 & $1 /$ & $/ /$ & , & 10000 & 8000 & 50000 & 11 & $/ 1$ & 1000 & // & & \\
\hline 4 & Sayd Abad & Sayd Abad & 11 & $/ 1$ & 5000 & 6000 & 6000 & $/ 1$ & 4 & : & // & 10000 & 11 & // & // & 1100 & "/ & & \\
\hline 5 & Lora & /I & // & 40 & 5000 & $/ 1$ & 6500 & $/ /$ & $/ /$ & & $/ /$ & 11 & 50000 & $1 /$ & 1500 & 1000 & $/ /$ & & \\
\hline 6 & Shash Qala & /I & /I & 35 & $/ 1$ & /I & $/ /$ & $/ 1$ & 3 & $\cdot$ & /I & 11000 & 4000 & 11 & 2000 & 1200 & /I & & \\
\hline- & Jang Jay & $1 /$ & $/ /$ & $/ /$ & $1 /$ & $/ /$ & 6000 & 11 & 1 & & $/ 1$ & 10000 & $/ 1$ & 11 & II & 1100 & $/ /$ & & \\
\hline 8 & Abdara & " & " & $" 1$ & 6000 & 6500 & 11 & 6000 & 3 & $\cdot$ & 11000 & 11000 & 50000 & 2200 & /I & 1000 & " & & \\
\hline 3 & Takya & /I & $/ /$ & 40 & 6000 & 6500 & 6500 & 7000 & $/ 1$ & & 10000 & $1000 \mathrm{q}$ & 40000 & 2000 & $/ /$ & 1000 & "I & & \\
\hline 11) & oteri & 11 & II & 35 & $1 /$ & 5500 & 6000 & 6500 & 2 & . & II & II & 11 & 11 & 1800 & 1200 & II & & \\
\hline 11 & & & & & & & & & & & & & & & & & & & \\
\hline 13 & & & & & & & & & & & & & & & & & & & \\
\hline 13 & & & & & & & & & & & & & & & & & & & \\
\hline 14 & & & & & & & & & & & & & & & & & & & \\
\hline
\end{tabular}




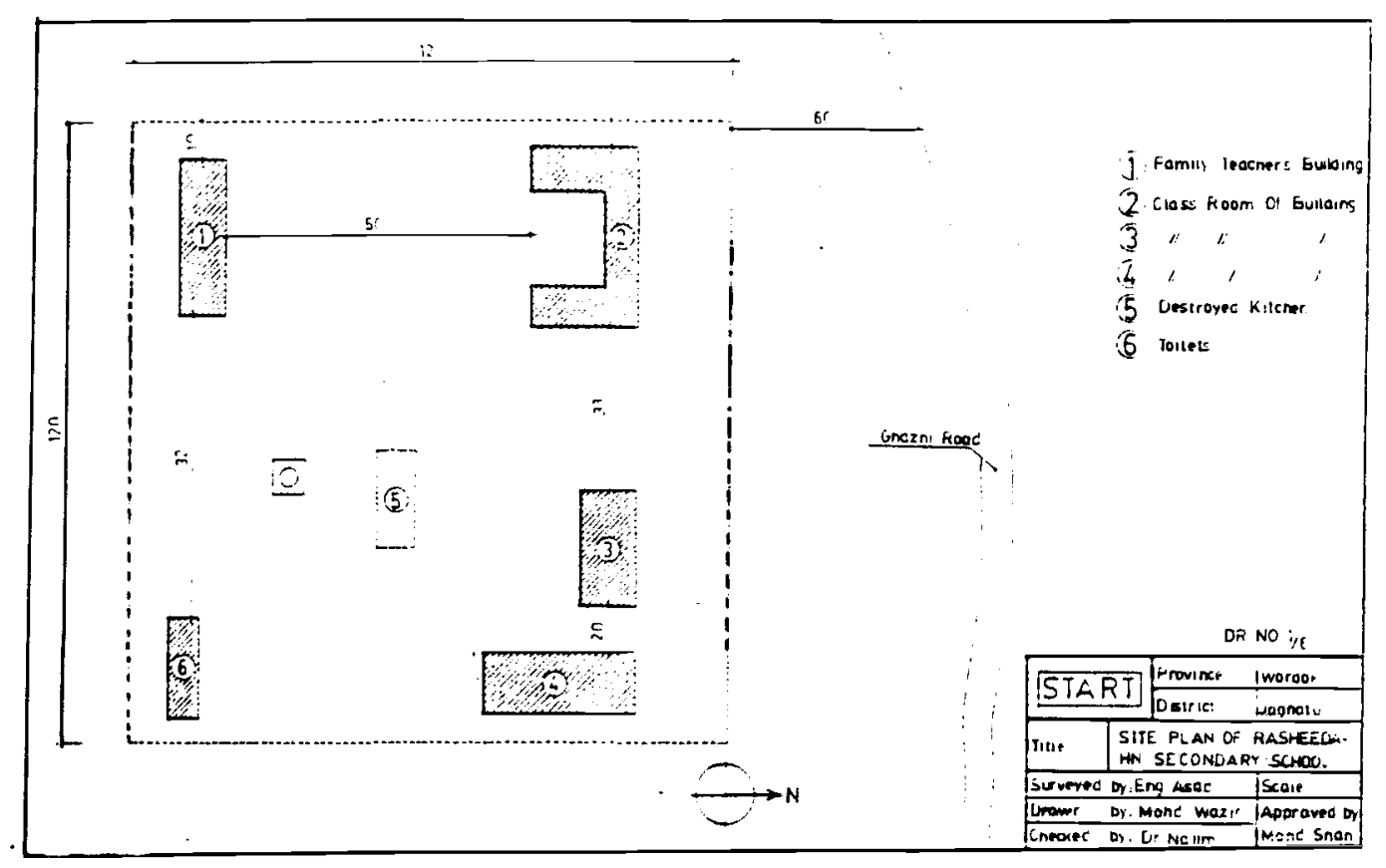

RASHIDAN SECONDARY SCHOOI:

This school is located in the western part of Jaghatu and covers an area of $120 \times 120$ meters land.

The building was roofed with timber and had six parts comprised of teaching rooms, residence for teachers, kitchen and toilets. The constructions vary in rate of destruction. The part is destroyed around $10 \%$ and is now used as center of Mujahideen.

There are about 4000 households living in the vicinity of the school, who sent their children to this school, before it was destroyed.

The parts of the school building is damaged $85 \%$. It had 10 classrooms, 3 bookstores, 1 teacher's room, 1 depot, 1 headmaster's of fice and a room for guards.

Doors and windows are missing. Walls are partly damaged and need a full repair. The kitchen is destroyed $90 \%$ and only traces of the foundations are visible.

In prewar era 250 students attended this school, it had 6 teachers, 1 head master, 1 director, and 2 peons.

Presently, Commander Sayed Ali has repaired 6 rooms of the building and has established a medical clinic which is used very much. The local administration wants to rebuild the school and would cooperate if possible. security is prevailing in the area and it makes a good site for rehabilitation projects. Semi skilled labor are found and local building material are available but wood is very expensive. 

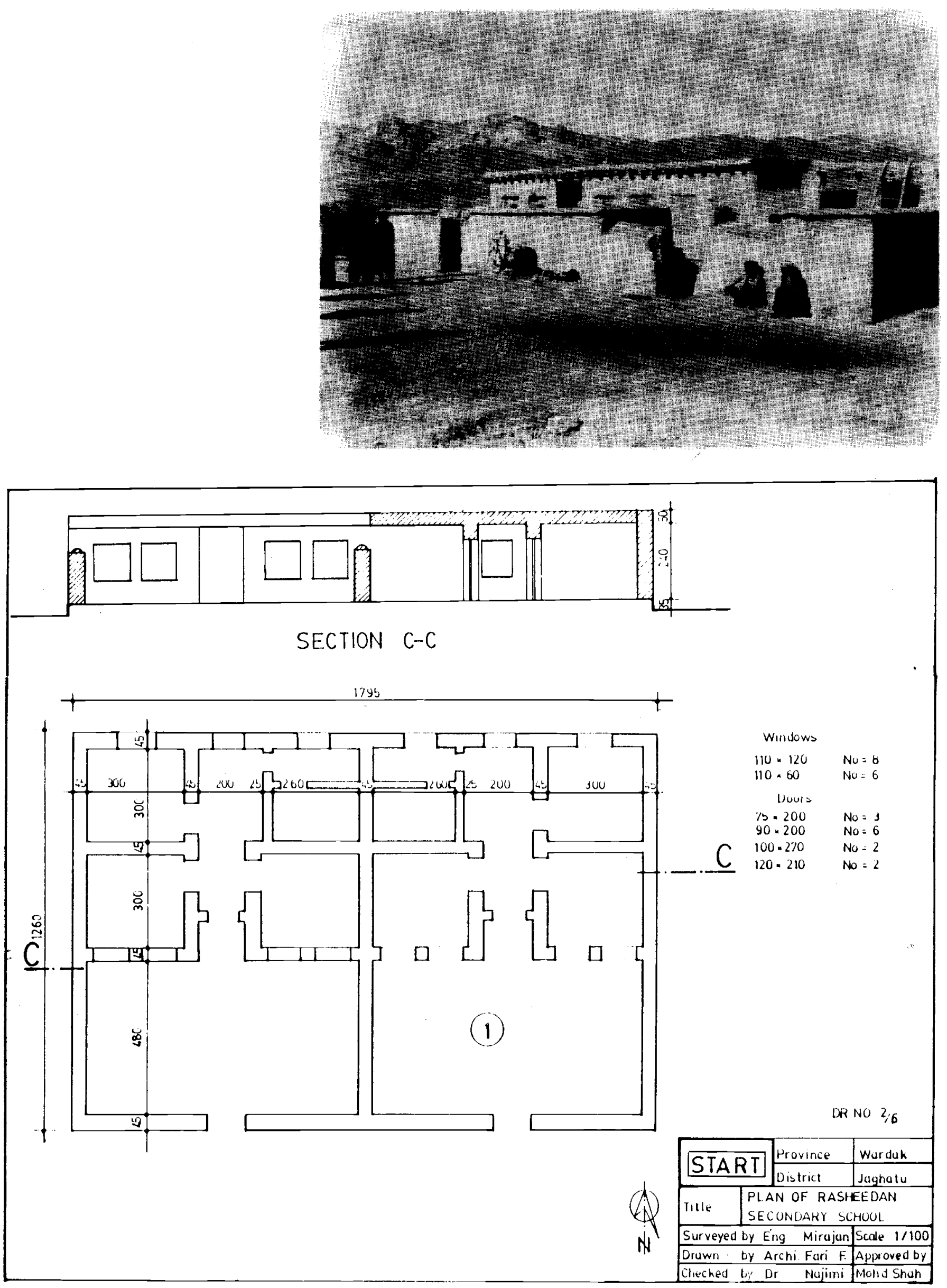

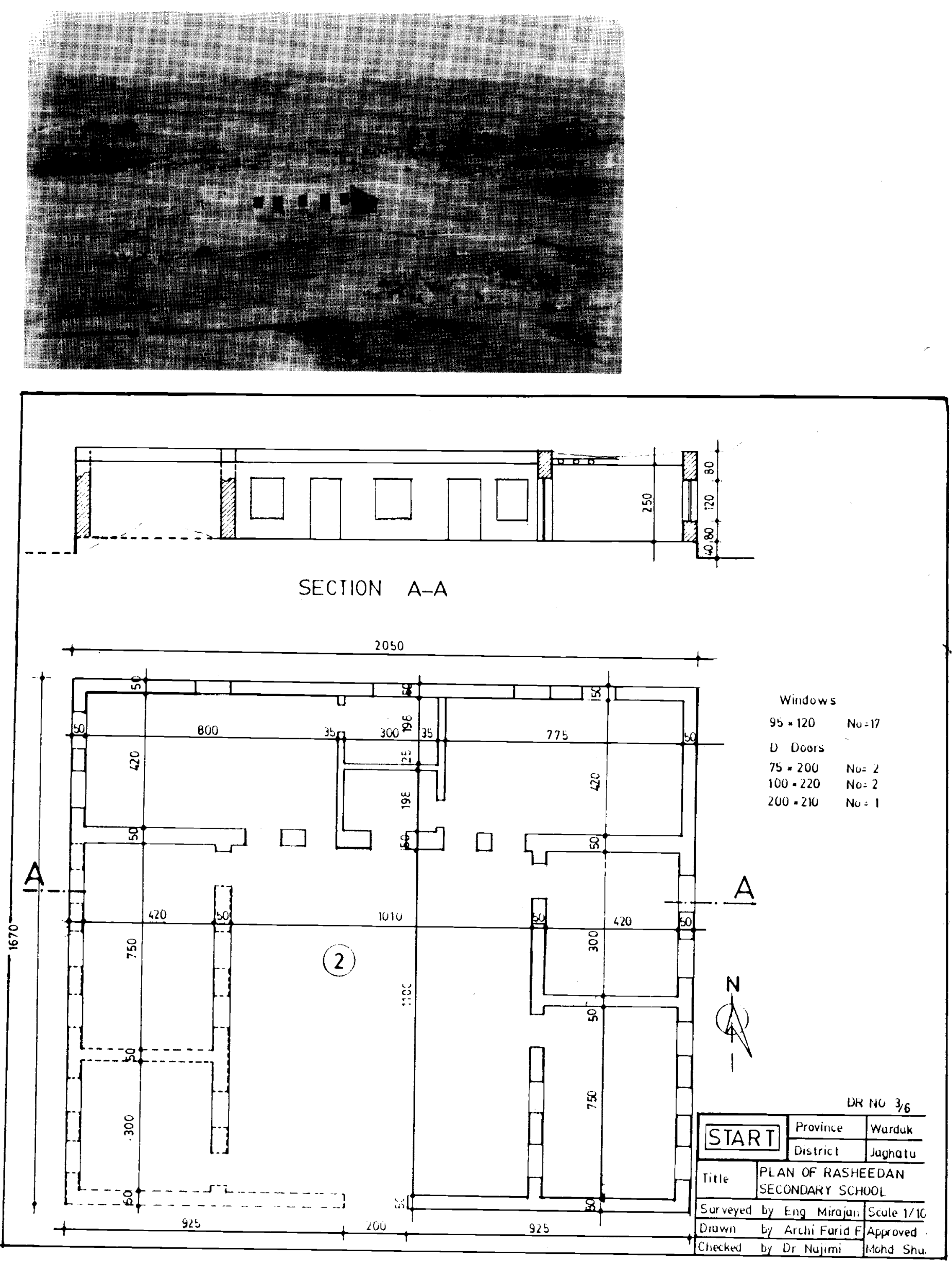

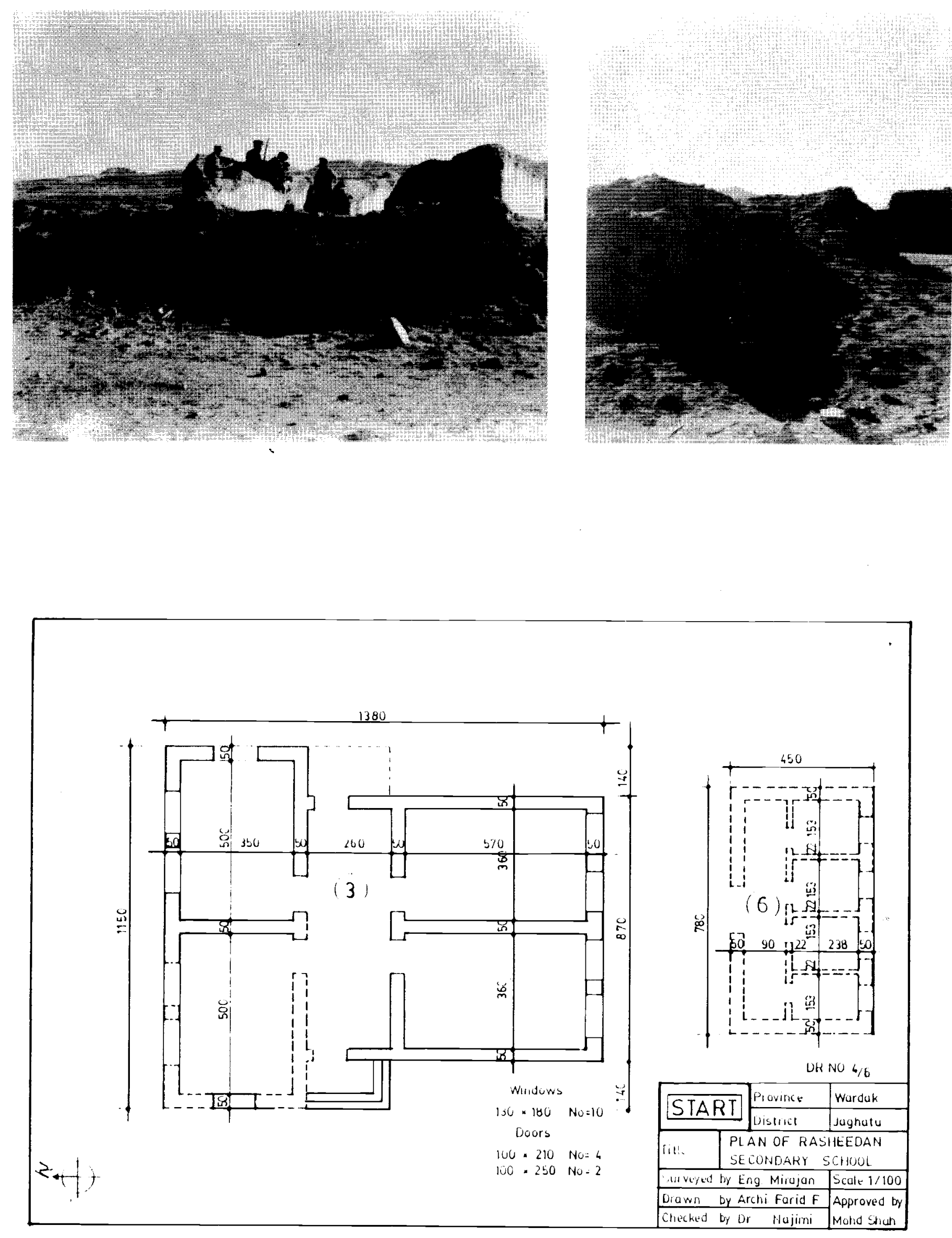

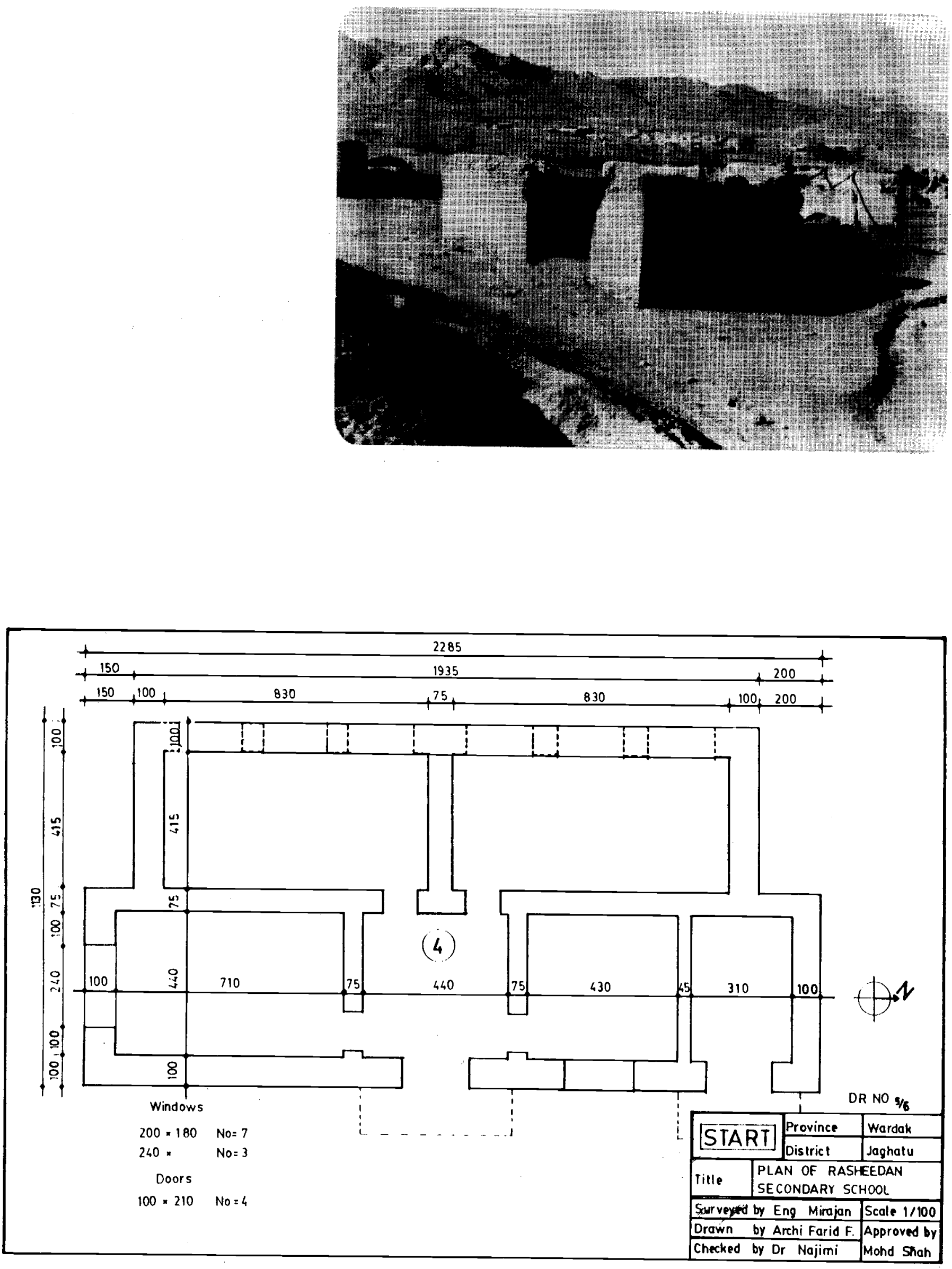


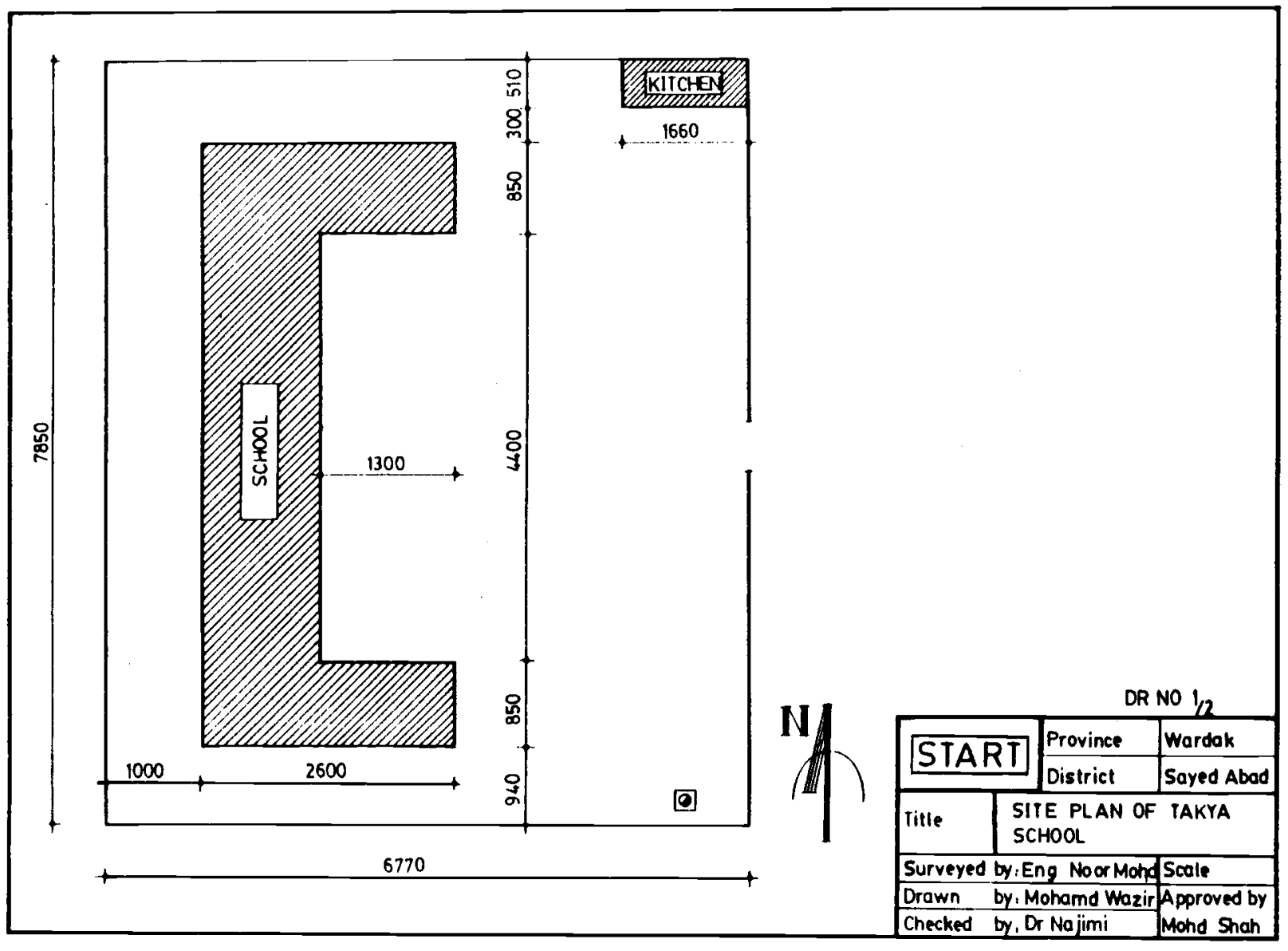

TAKYA SECONDARY SCHOOL:

Located in Takya in the middle of Shniz valley. The Kabul-Ghazni route passes through this area. The building covered $78 \times 64 \mathrm{~m}^{3}$ and was built of mud walls and timbers roofing. It had 22 rooms 12 classrooms, 2 teacher's rooms, one library, one laboratory room, one administrator, one guard room and 4 rooms for kitchen and residence.

During the war roof timbers, doors and windows were destroyed and the walls were destroyed during a military operation in July 1986 by the Kabul government troops. Only the stone foundations are remaining. The walls were $60 \mathrm{~cm}$, wide.

There are about 1000 families close to the school. Their children and children from other remote villages were before the war coming to this school for learning,

The inhabitants want the school to be rebuilt and the local commander is friendly and cooperative. Security is prevailing and local building materials is available but wood is very expensive. 

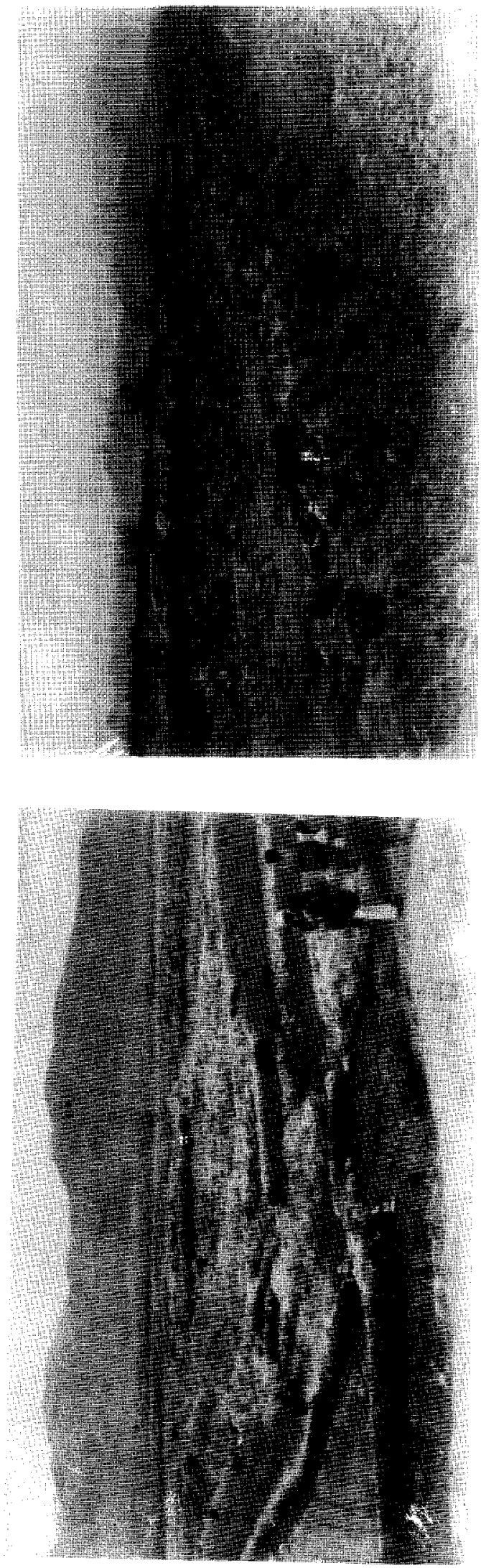

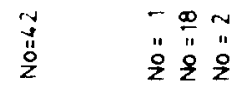

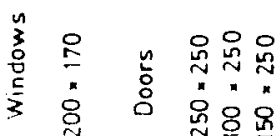
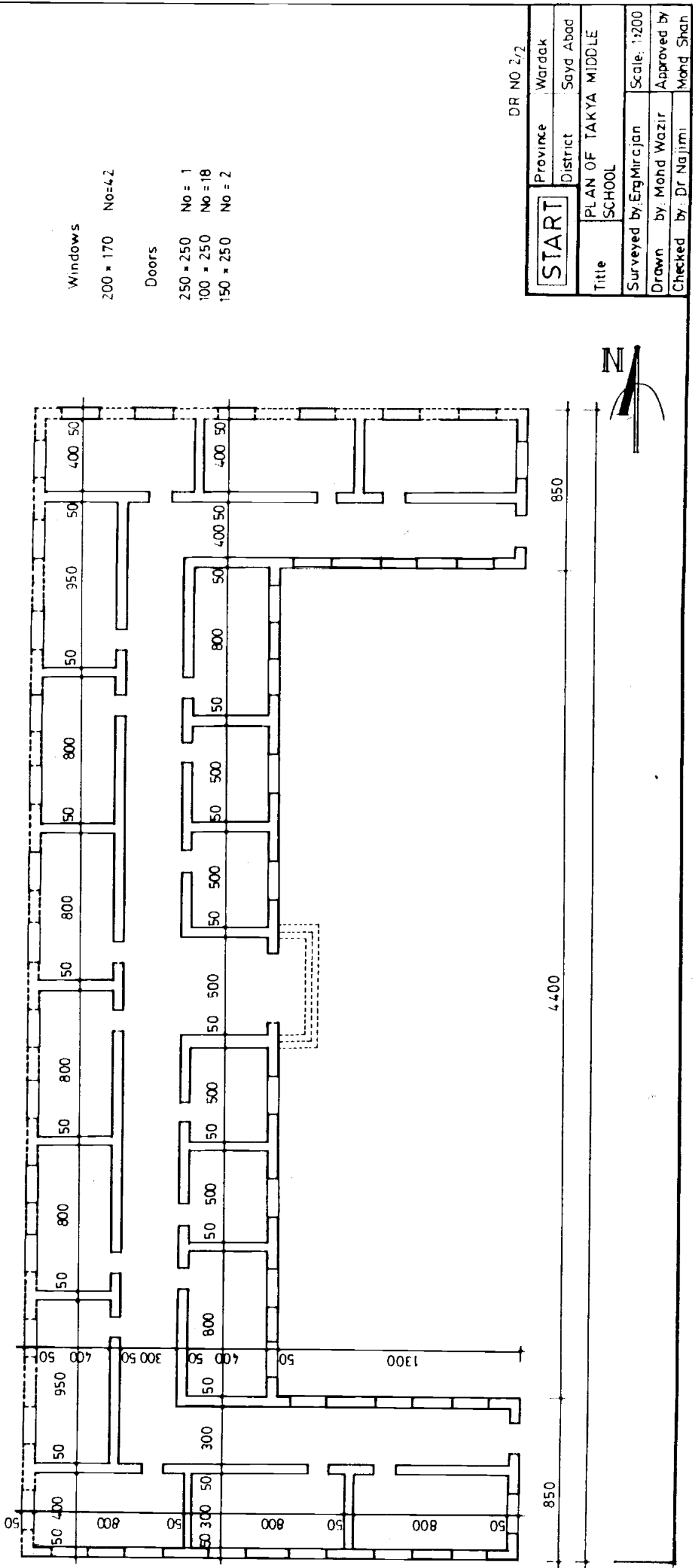


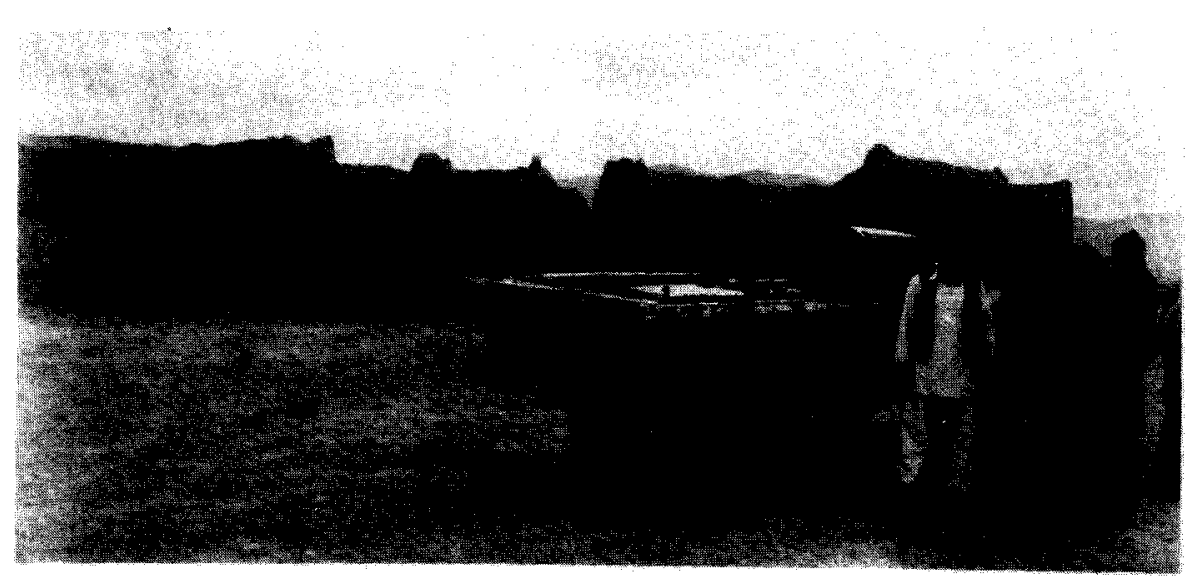

\section{SHAH QALA SECONDARY SCHOOL:}

This school covered the area of $54 \mathrm{~m} \times 19 \mathrm{~m}$. the building has been badly damaged during the war and only stone foundations are remaining. The building consisted of 10 classrooms, 1 teacher room, 1 store, and bookstore.

About 3000 households are using this school for education of their children. The people wants this school be rehabilitated and the local commander Mawlavi Sayed Rahman is friendly and cooperative.

Building material is available, but wood is expensive and should be imported from other areas.

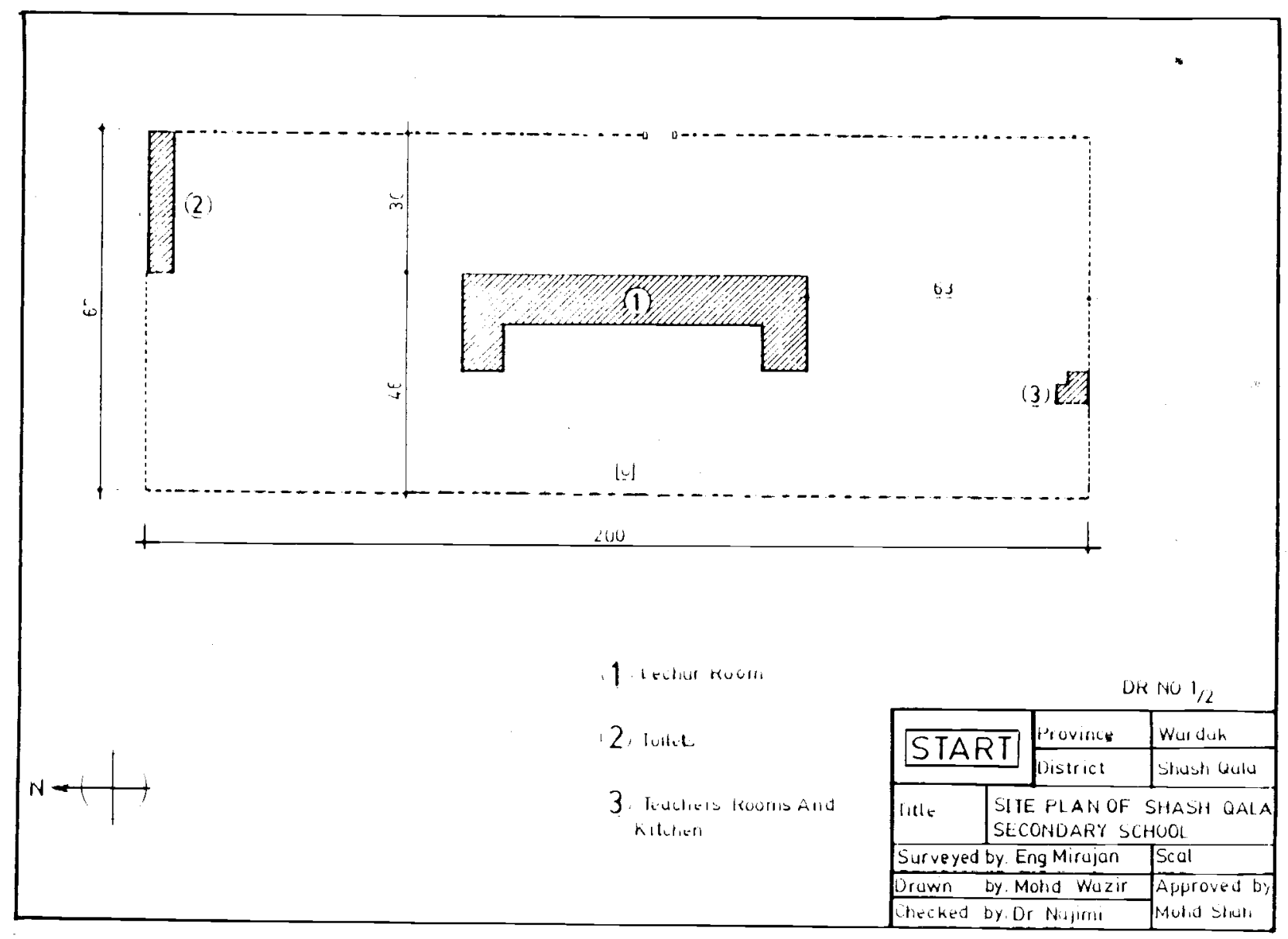



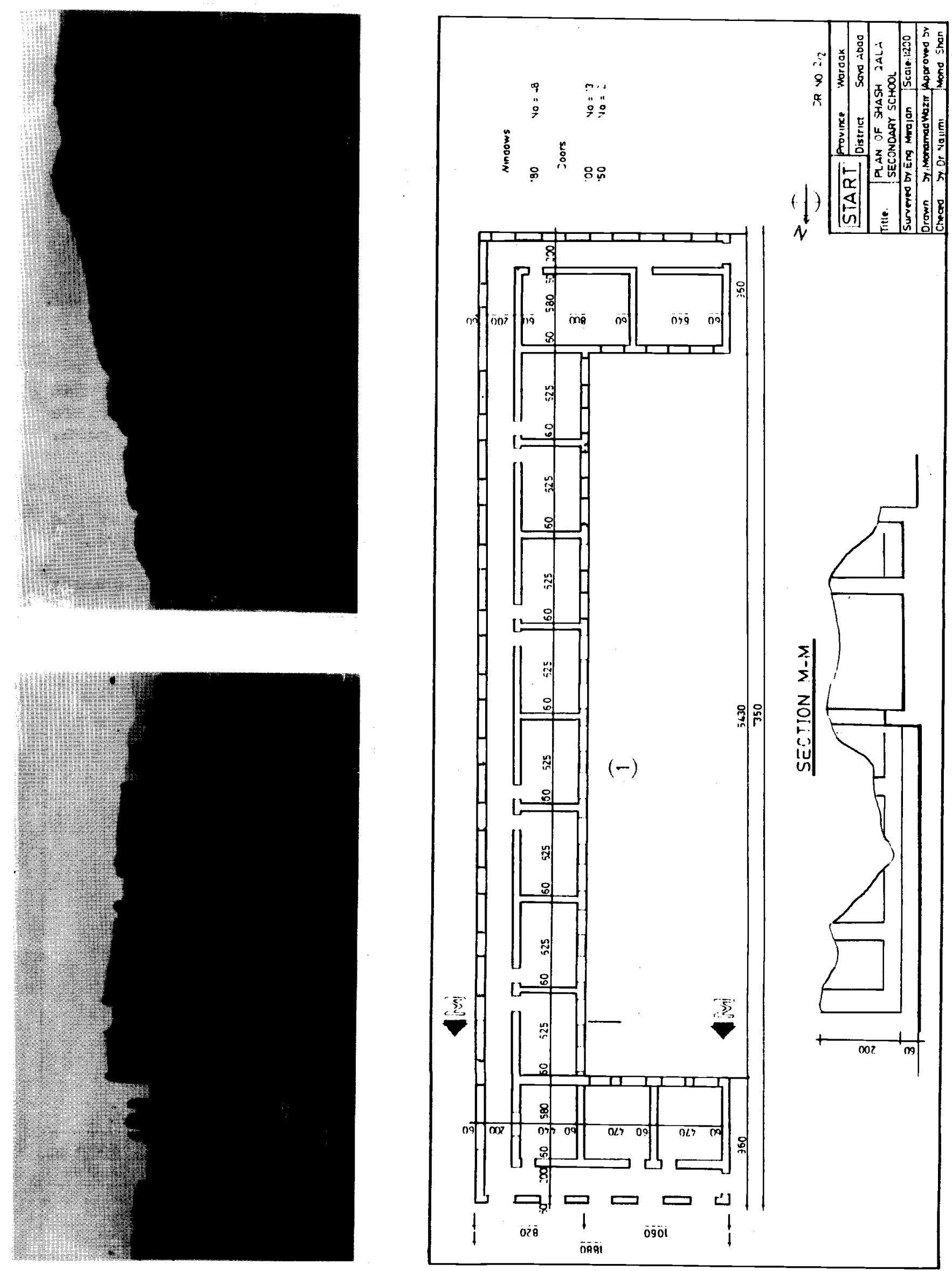


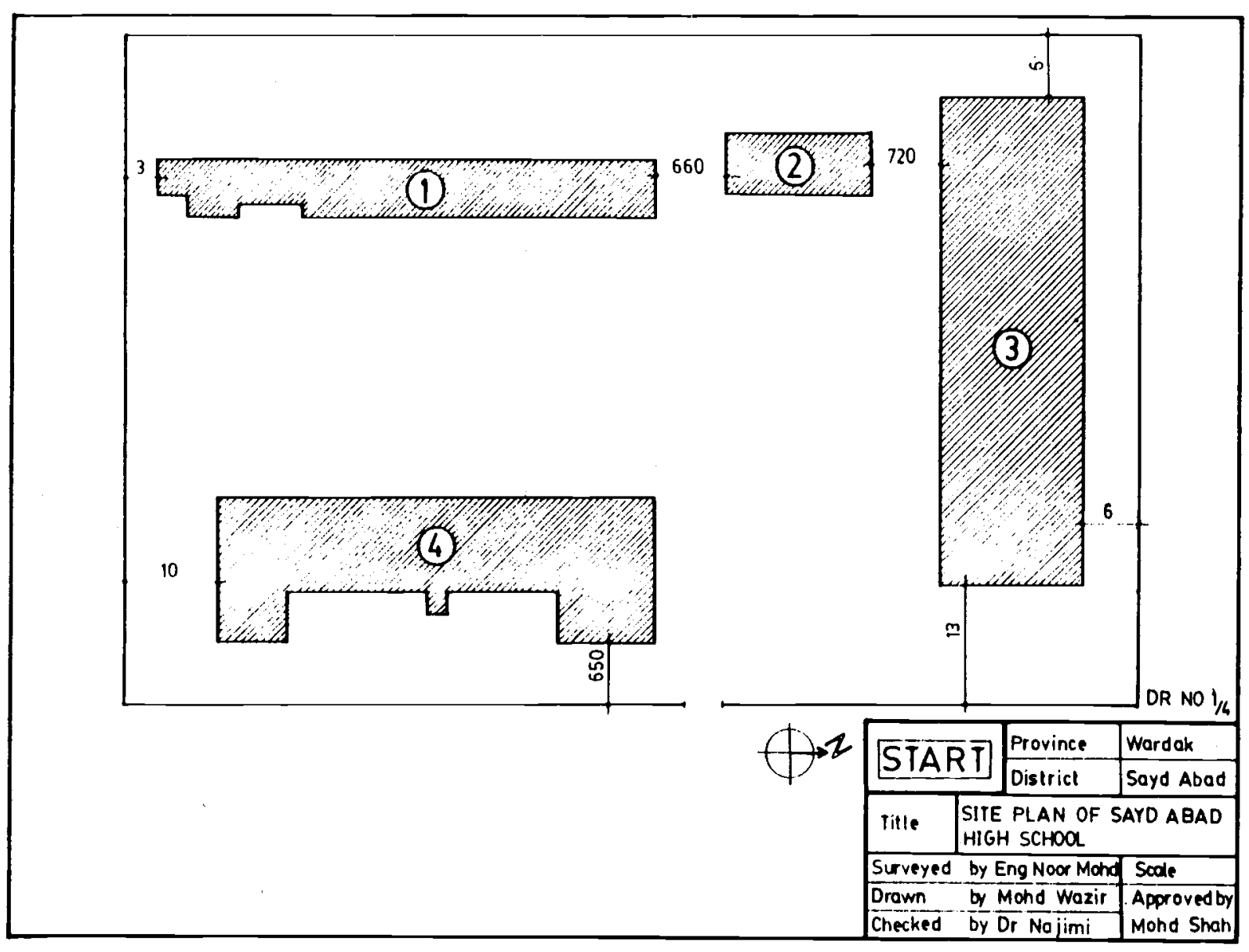

SAYED ABAD HIGH SCHOOL:

This school was built by the Kabul - Ghazni asphalted - high way passing through the south of Sayed Abad administration center. Part of the school covers an area of $46 \times 17 \mathrm{~m}$. The foundations were built of stones and walls where made of fined bricks. The school building consisted of a classroom, library, teachers room, Administration and laboratory. Other three parts of the school were built of sun-dried bricks. Rooms made a height of 3.30 meter. The roofs, doors and windows are all destroyed and disappeared due to bombings and artillery attacks. The walls are destroyed about $60 \%$. The other part of school which consists 3 classroom, and administration. office is also destroyed and only $20 \%$ wall is remaining.

The third part of the complex consists strong and covers a land of about $13 \times 6$ meters, it had stone foundation and walls of sun-dried bricks. Today it is destroyed.

The fourth part of the complex consists of 12 classrooms that covered an area of $46 \times 13$ meters. It is built of mud walls of $60 \mathrm{~cm}$ wide. Only walls remain to a height of 2 meters. People want the school rebuilt and conditions for resettlement will be convenient and due. 

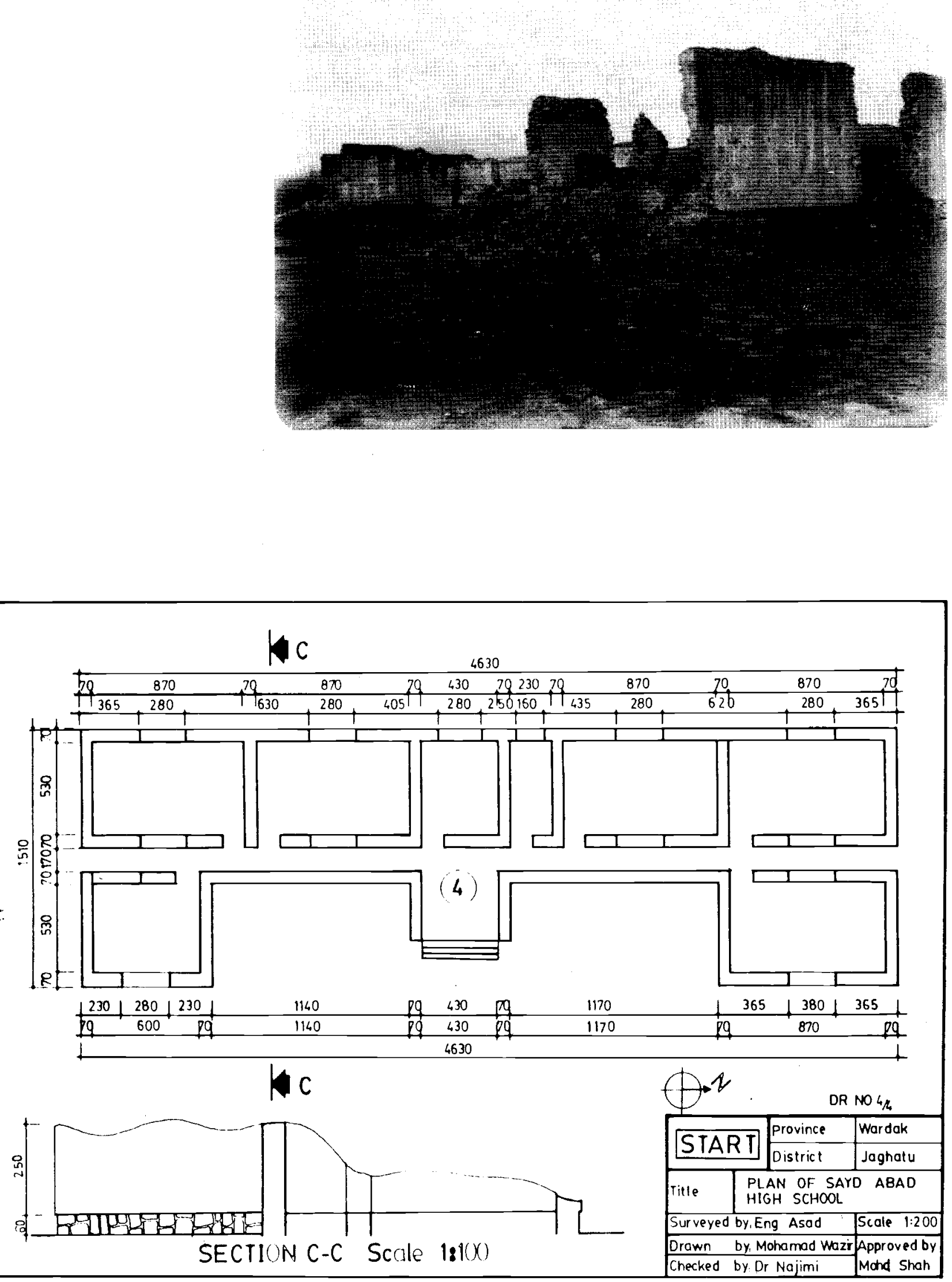

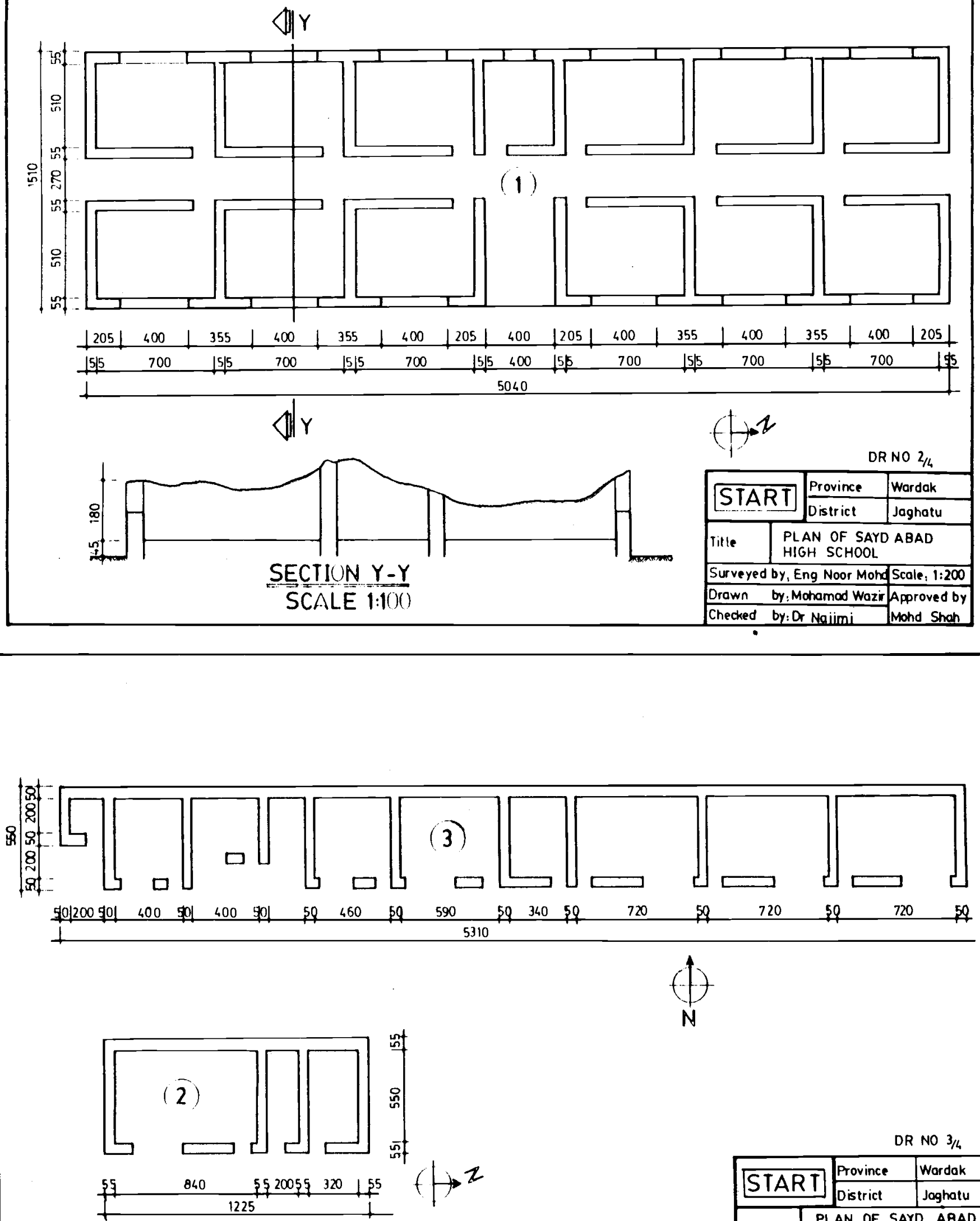

DR NO $3 / 4$

\begin{tabular}{|c|c|c|}
\hline \multirow{2}{*}{ START } & Province & Wordak \\
\hline & District & Joghatu \\
\hline Title & $\begin{array}{l}\text { PLAN OF SAY } \\
\text { HIGH SCHOOL }\end{array}$ & $D$ ABAD \\
\hline \multicolumn{2}{|c|}{ Surveyed by: Eng Asad } & Soole $1: 20$ \\
\hline Drawn & by, Mohamad Wazir & Approved b \\
\hline Checked & by, Dr Nojimi & Mohd Shat \\
\hline
\end{tabular}




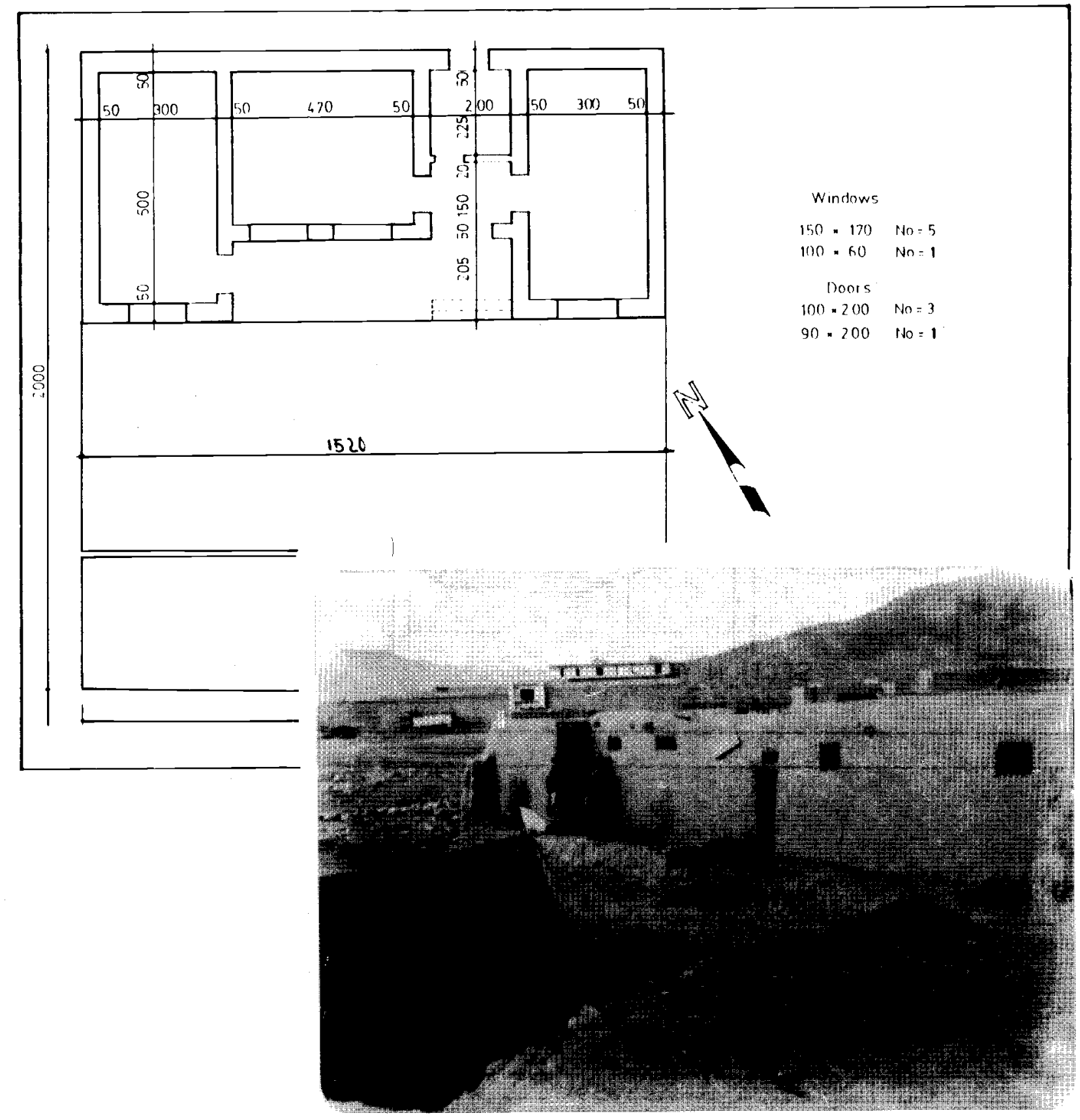

JAUNG-JOY PRIMARY SCHOOL:

This school is located in a village having about 30 households. It covers an area of $20 \times 15$ meters and has 6 classes, one bookstore, one teacher office and one administration. The building has timber roof which has been demolished as the result of war and bombings. Only two rooms are occupied by the local commanders and is used regularly as medical clinic of Abdara front. The other rooms are destroyed and only the stone foundation is remaining.

Although the building is damaged $80 \%$, as there is not any other school in the proximity of about $2 \mathrm{~km}$., therefore, the inhabitants want the school to be rehabilitated. Building material such as stones, sand, mud are available and wood can be procured from a distance of about $2 \mathrm{~km}$. 


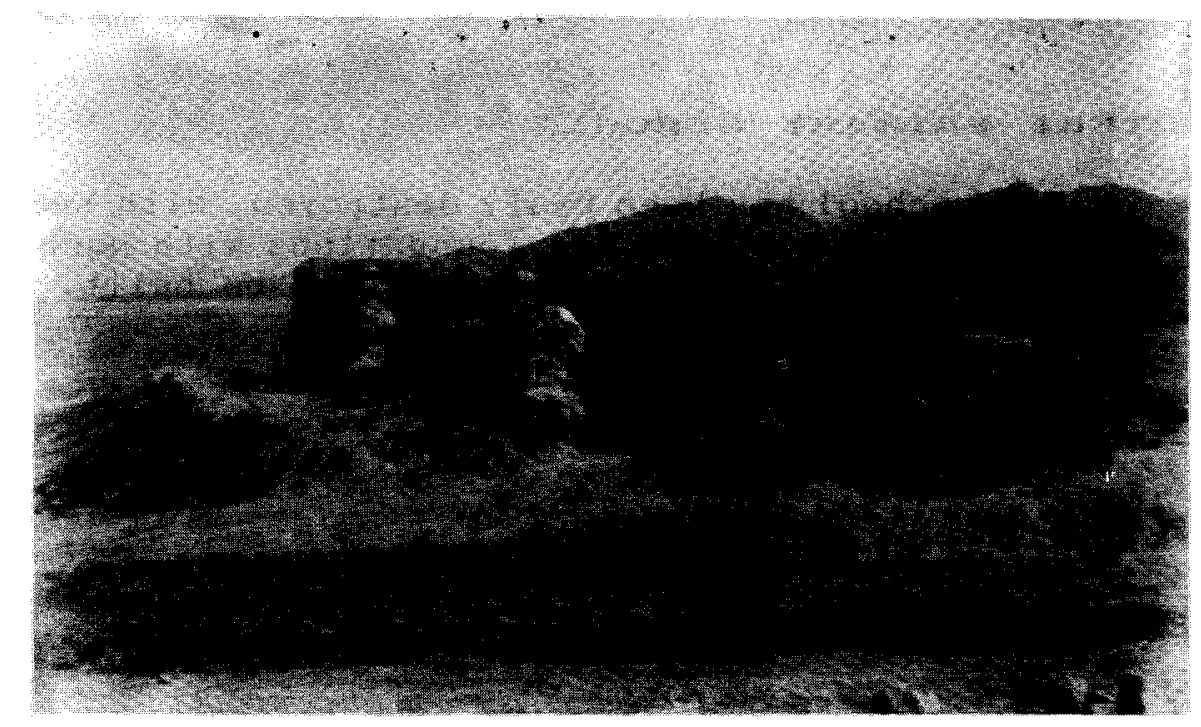

LOFA PRIMARY SCHOOL:

This school is located in the upper Shniz and covers an area of approx. $20 \times 20$ meters. There are about 500 households inhabited in this area. The school consists 4 classrooms, one teacher's room, one administration and a kitchen. The building is demolished but the stone foundation is remaining.

The inhabitants expect to rehabilitate the school and expand it to more classrooms. Local building material are available.

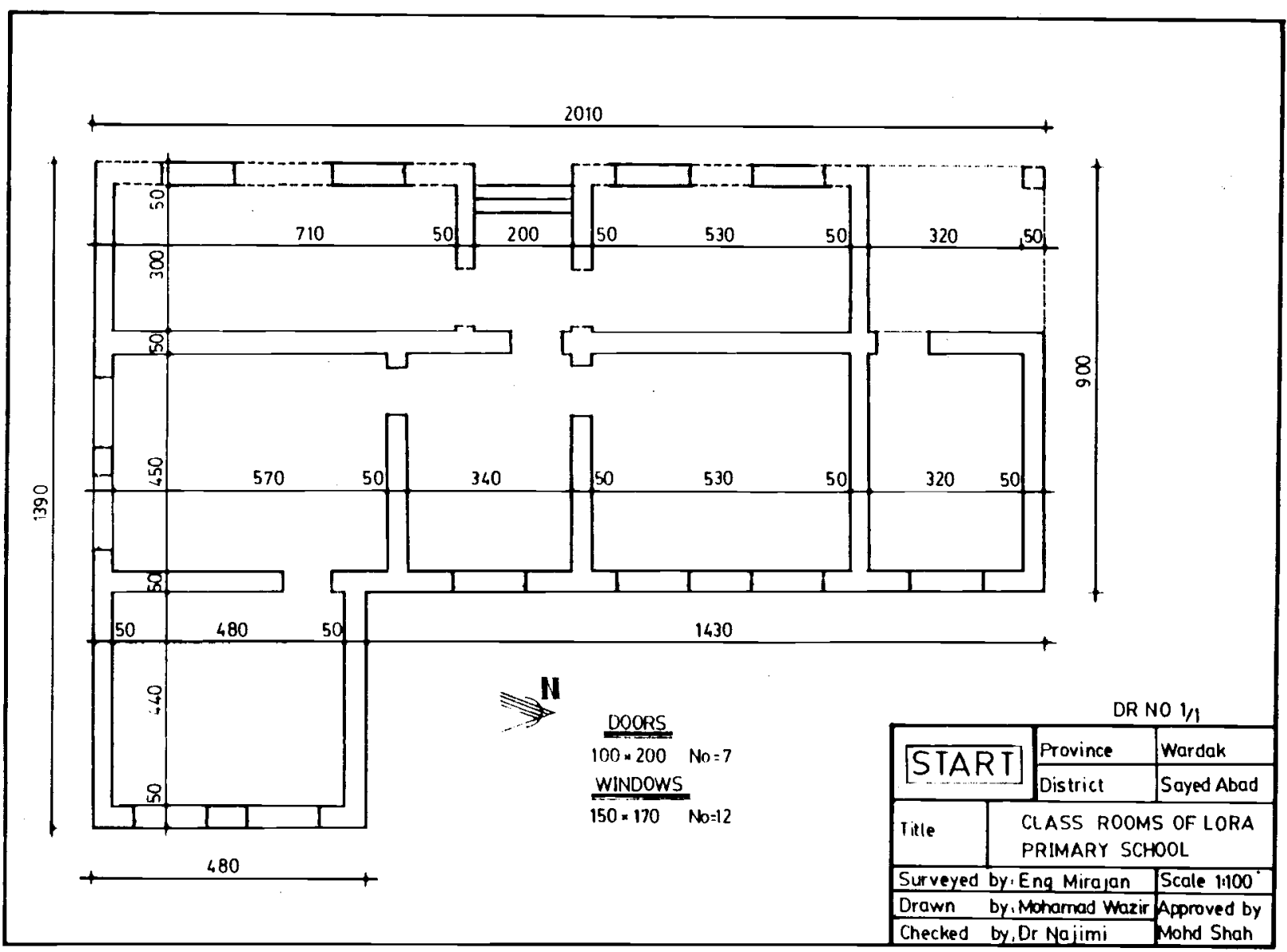


This school has been badly destroyed, with such position that one would trace the site and the foundations with much difficulty. People of the area badly need a new school to be built.

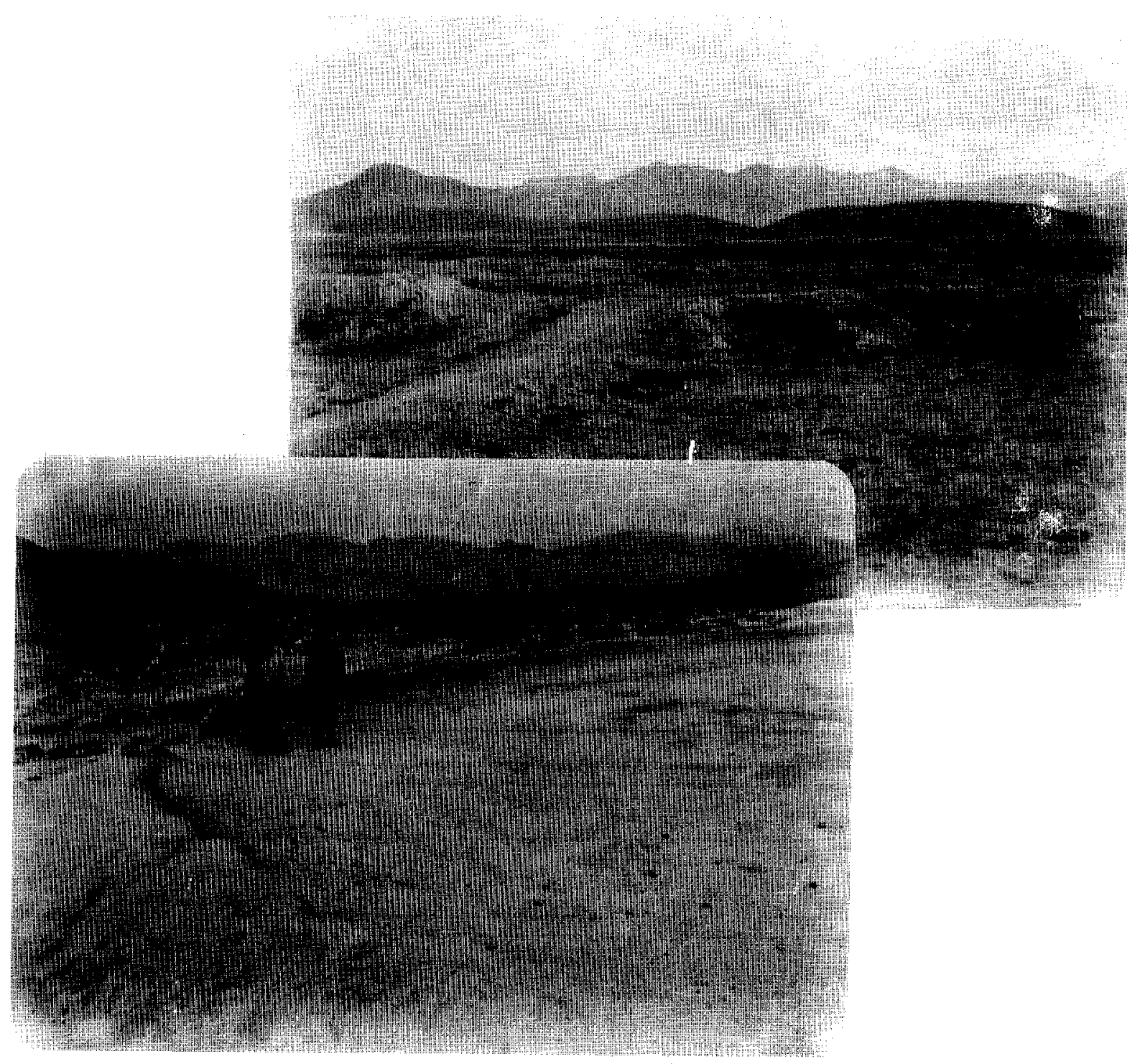

abdara primary SCHOOX:

Abdara is a remote village located far away from the asphalted high way and in the upper Shniz. The school here provided education for children of more than 40 households.

The building is damaged entirely and there is no other school in the vicinity either. The inhabitants and the local commander, Akhund Zada of Harakat Nabi, are keen on the rebuilding of the school launching education programme this remote settlement.

Building material such as mud, stone, aggregate and sand are available from the local hills and river and wood can be procured from other places but very expensive. 


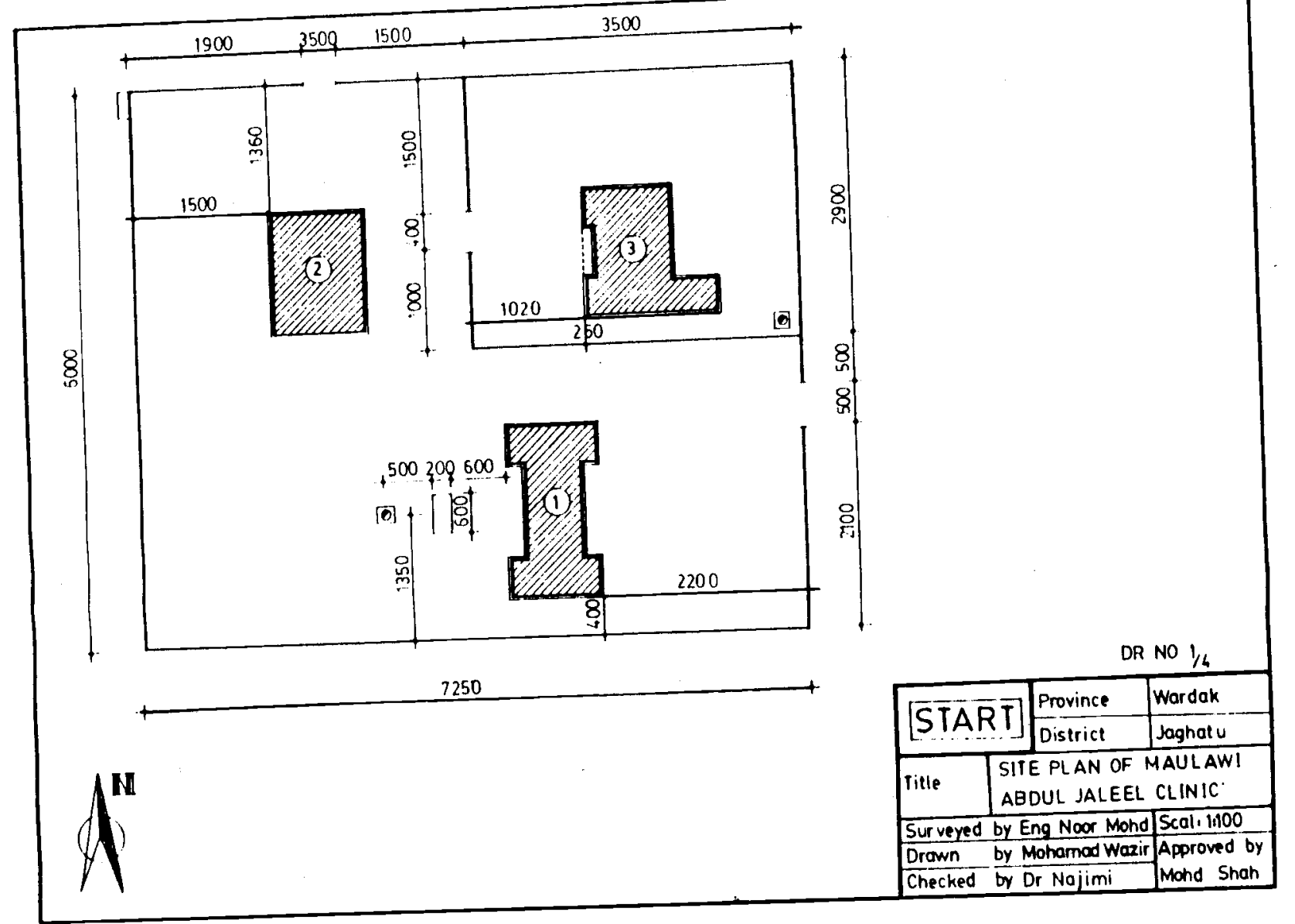

CLINIC OE SHAHEED

MaULAVI ABDUL JALEEL

This clinic was constructed in 1976 with the following specifications:

Dimension : $72.5 \mathrm{~m} \times 60 \mathrm{~m}$

Type of construction : Stone and Concert

Roof \& Floor: Concreted

The quarter is divided by three portions:

1. Clinic of Maulavi Abdul Jaleel related to Harakat-Nabi and here certain 80 patients are treated daily. The clinic having 6 rooms and 2 bath rooms on the area of $10 \mathrm{~m} \times 18.20 \mathrm{~m}$.

The quarters have sheet metal roofing, 9 doors and 10 windows, but all destructed and/or taken-away.

2. The second portion of the quarter consisting of 9 rooms, 10 doors and 8 windows. The internal plaster on the floor is in proper way but the doors and windows not available. The total destruction estimated $30 \%$.

3. The third part of the quarter with dimension of $14.5 \mathrm{~m} \times 13.30 \mathrm{~m}$ having 5 rooms, hall, 7 doors and 7 windows, no inside plaster. The range of destruction is $40 \%$ 

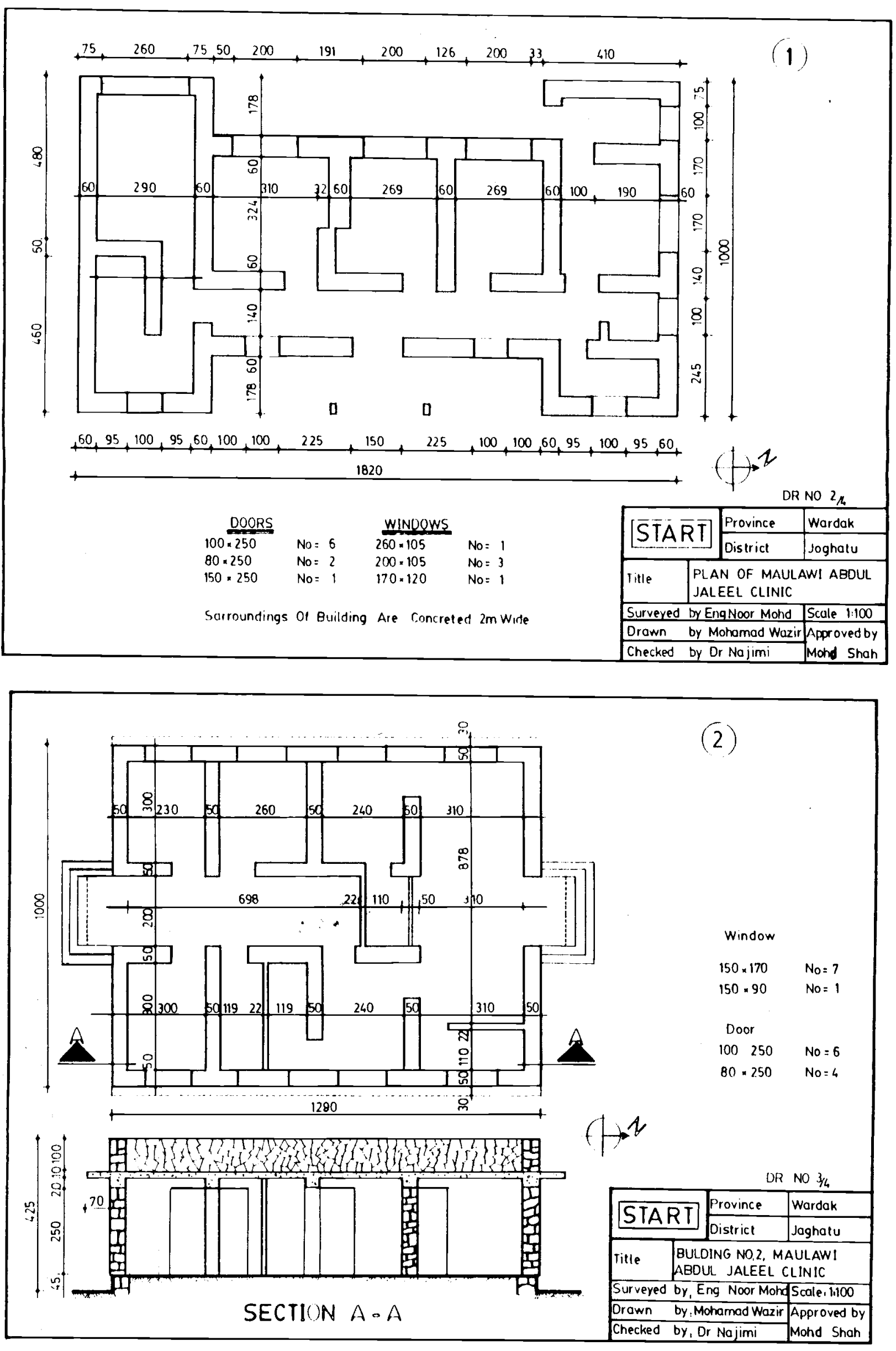

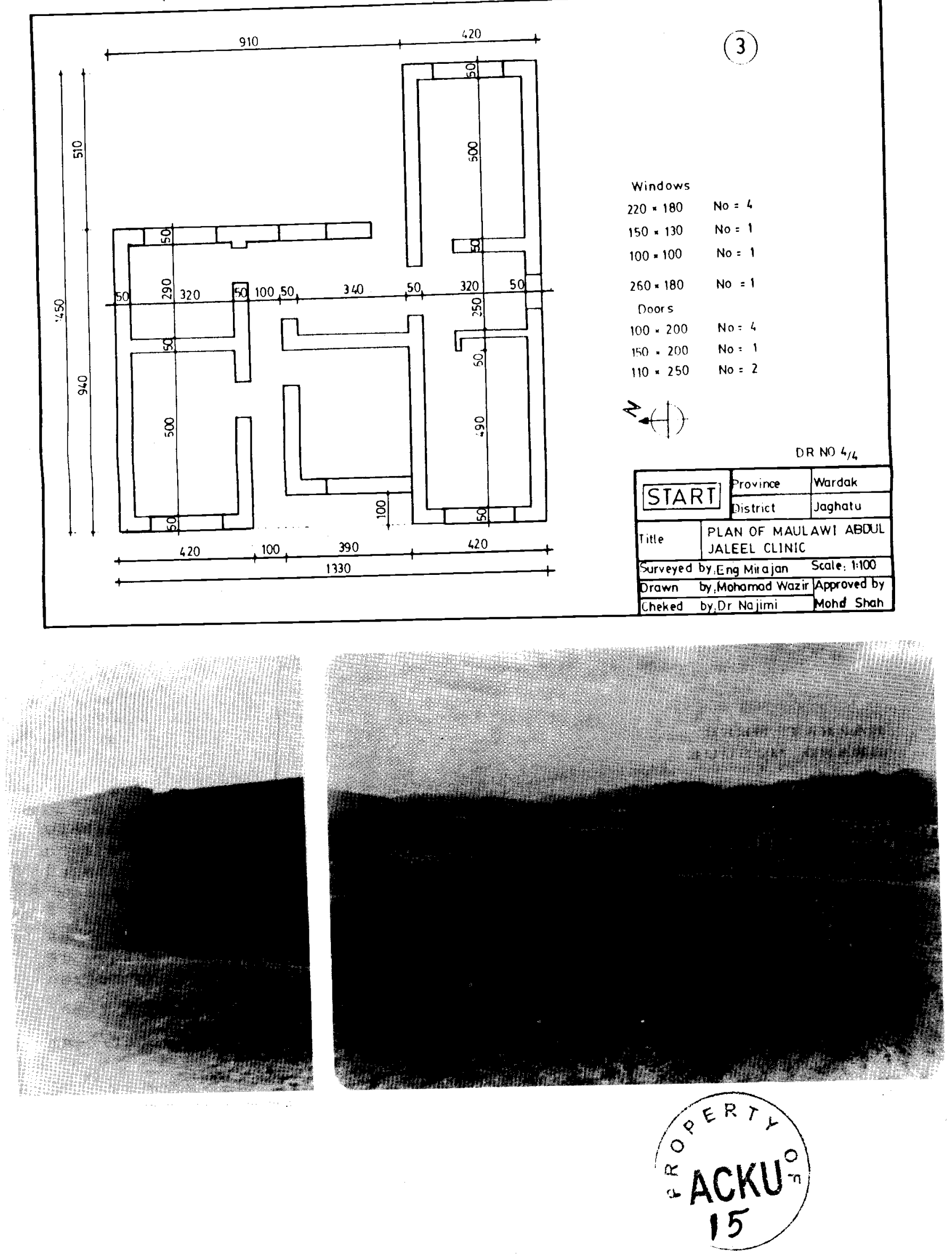


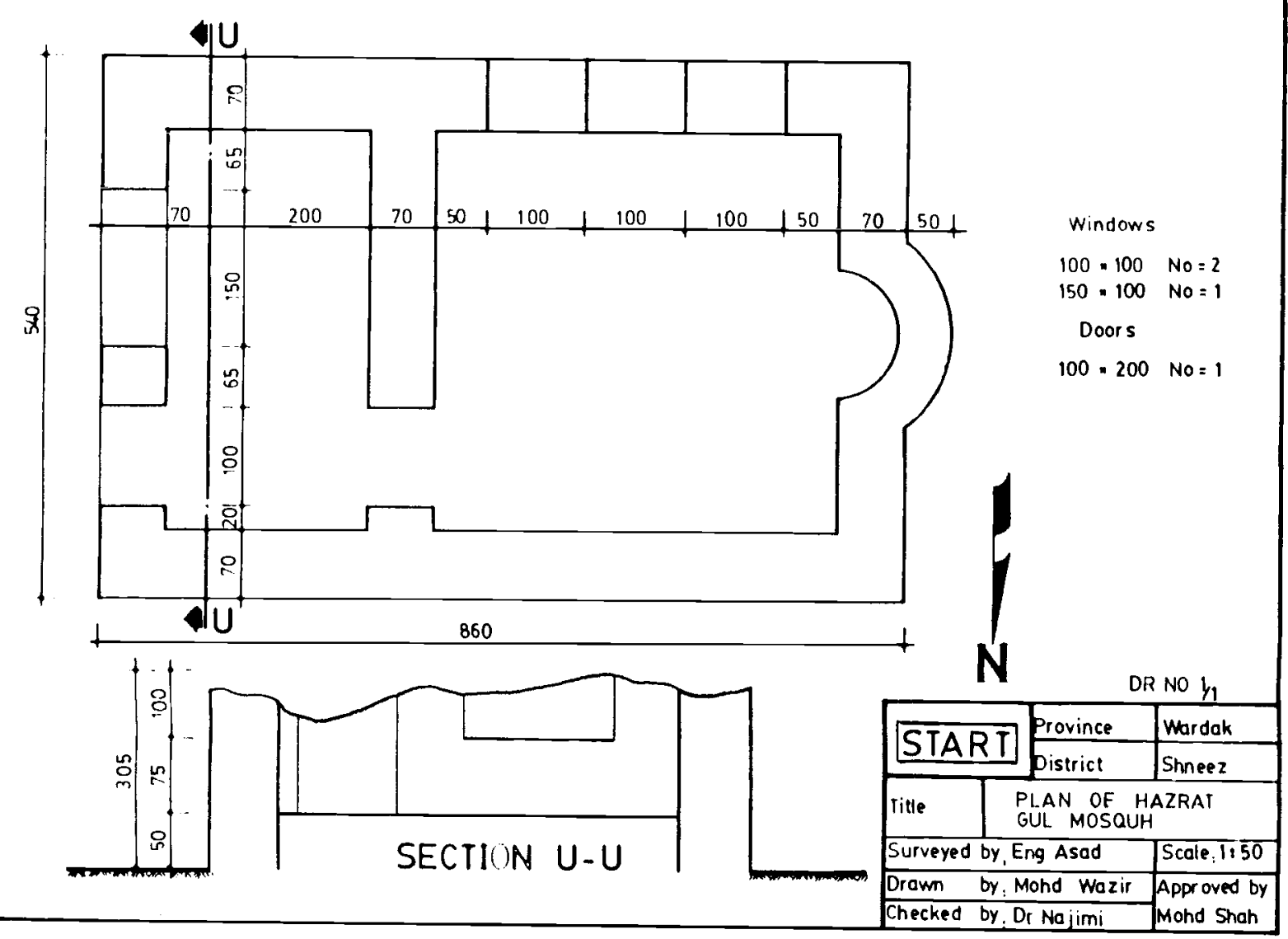

HAZRAT MEER

GRAND MOSQUE

The mosque was built in Abdul Muhayuddin village, Chaghatu district. The solid mud masonry wooden roof mosque was built on the area with dimension of $8.60 \mathrm{~m} \times 5.40 \mathrm{~m}$. The mosque is damaged by bombardment, having no doors, windows and roof.

150 families are living towards the mosque who pray and obey their religious observations. Reconstruction of this mosque is proposed by the inhabitants who promised any possible cooperation af forded.

Construction materials like earth, sand, stone and timber/beam can also be found nearly. 


\title{
ST A RT
}

\author{
PHOTOGRAPH
}

SURVEYED BY: Eng Noor.Mohd

PREPARED BY' . Eng. Mirajan

\begin{tabular}{|c|c|c|}
\hline FROVINCE: & DISTRICT: & VILLAOE: \\
\hline ..........Wardak .... & Shne.ez. &  \\
\hline
\end{tabular}

DESCRIPTION:

HAZRAT GUL MOSOUUE 


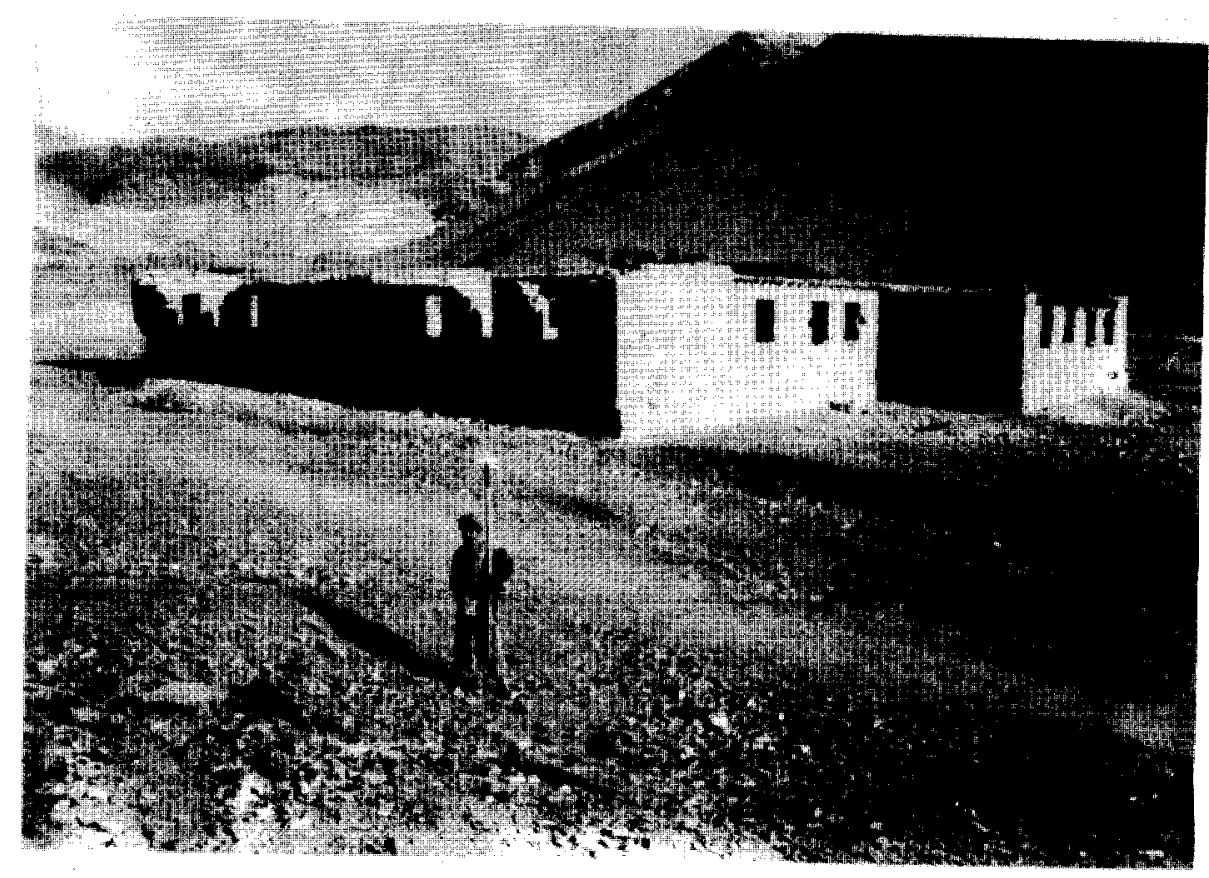

PRYMARY SCHOOL OF JOE ZAREEN :

This stone built school is partly destructed. Repairing of its roof and walls can smoothly be done. The photos available shows the present condition.

The school was built on 753.19 sqm having 10 class-rooms.

Graduates of 6 th class of this school had been joining the Karim Khan Secondary School in Daulat Khail village.
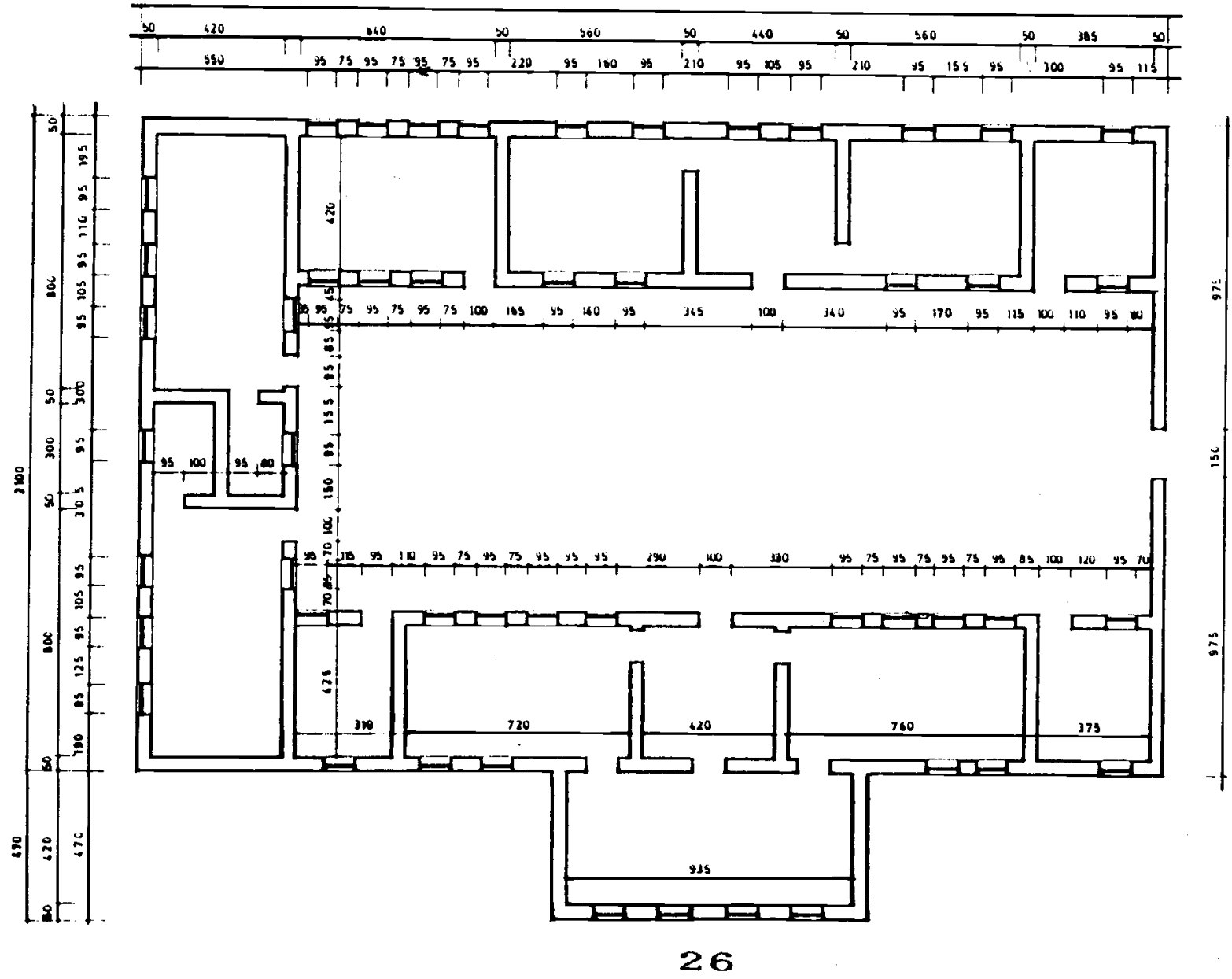


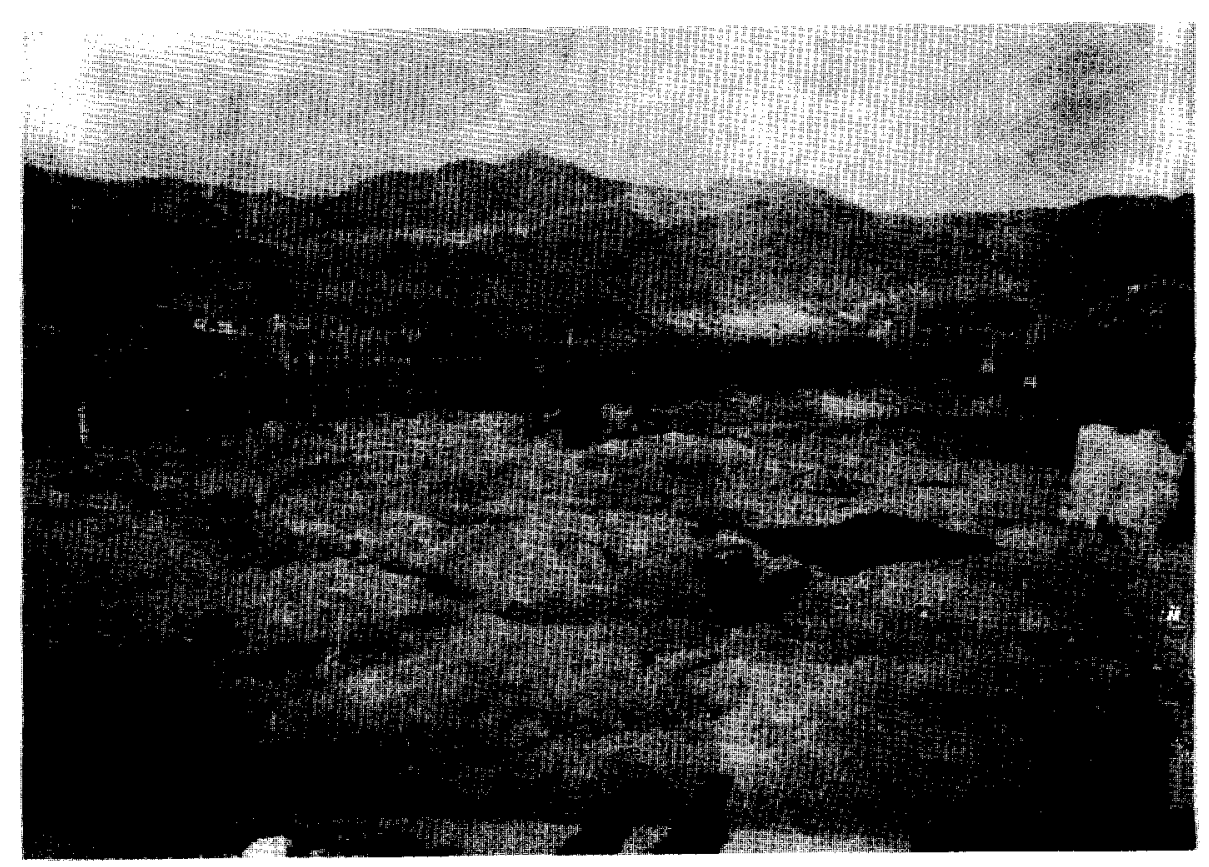

SHATKH ABAD SECONDARY SCHOOL:

This school is among the others completely destructed. Except some dried mud gathered over nothing is remained.
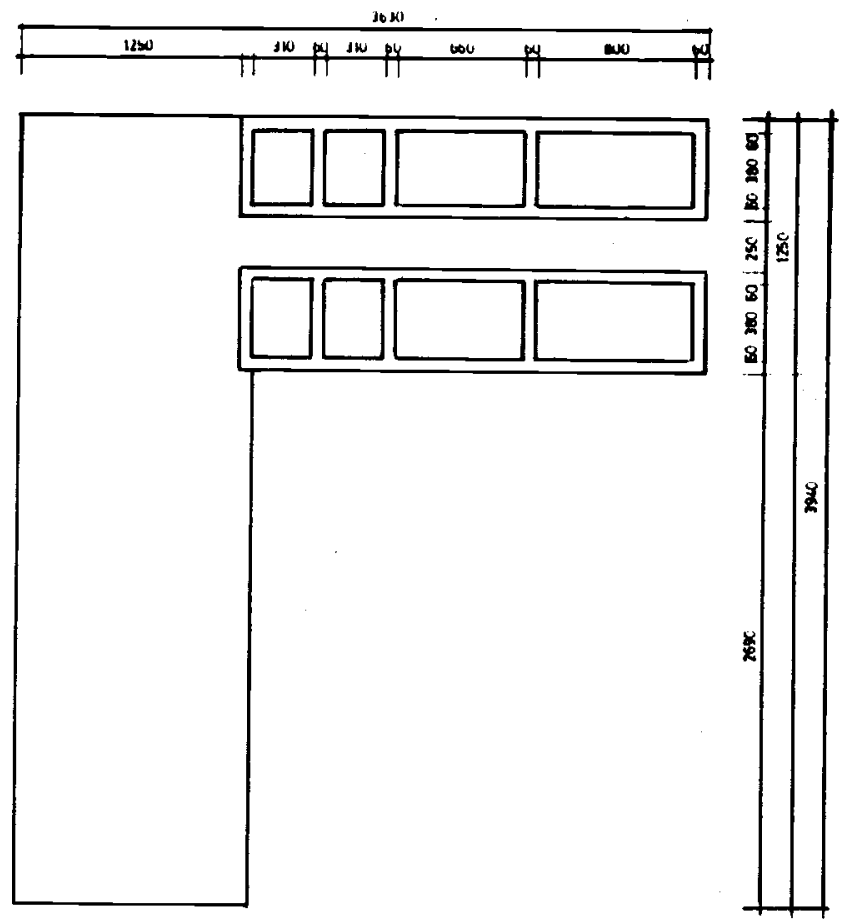

PL,,$N$

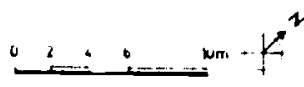

\begin{tabular}{|c|c|c|}
\hline STQR & Frorimes & wardout \\
\hline & Uasin & Cous \\
\hline I,14 & $\begin{array}{l}\text { Sian } \\
\text { Secton }\end{array}$ & $\begin{array}{l}\text { Ahuou } \\
\text { ury sclow }\end{array}$ \\
\hline
\end{tabular}




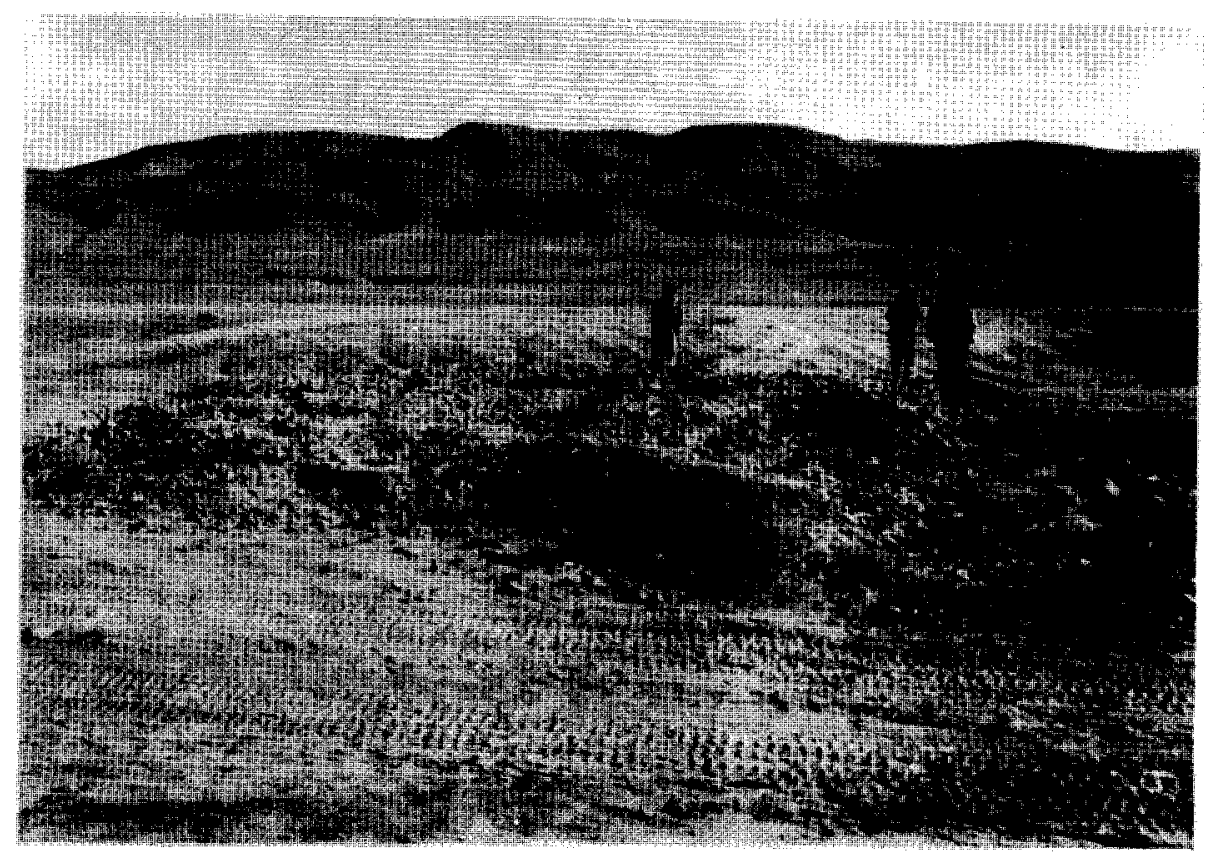

TOPE SECONDARY SCHOOL:

It was a primary school then promoted to secondry level. It was fully destructed, except some small particles of bricks nothing remained. The students of the school were locally and those coming from Ala Sangh and other neighboring villages.

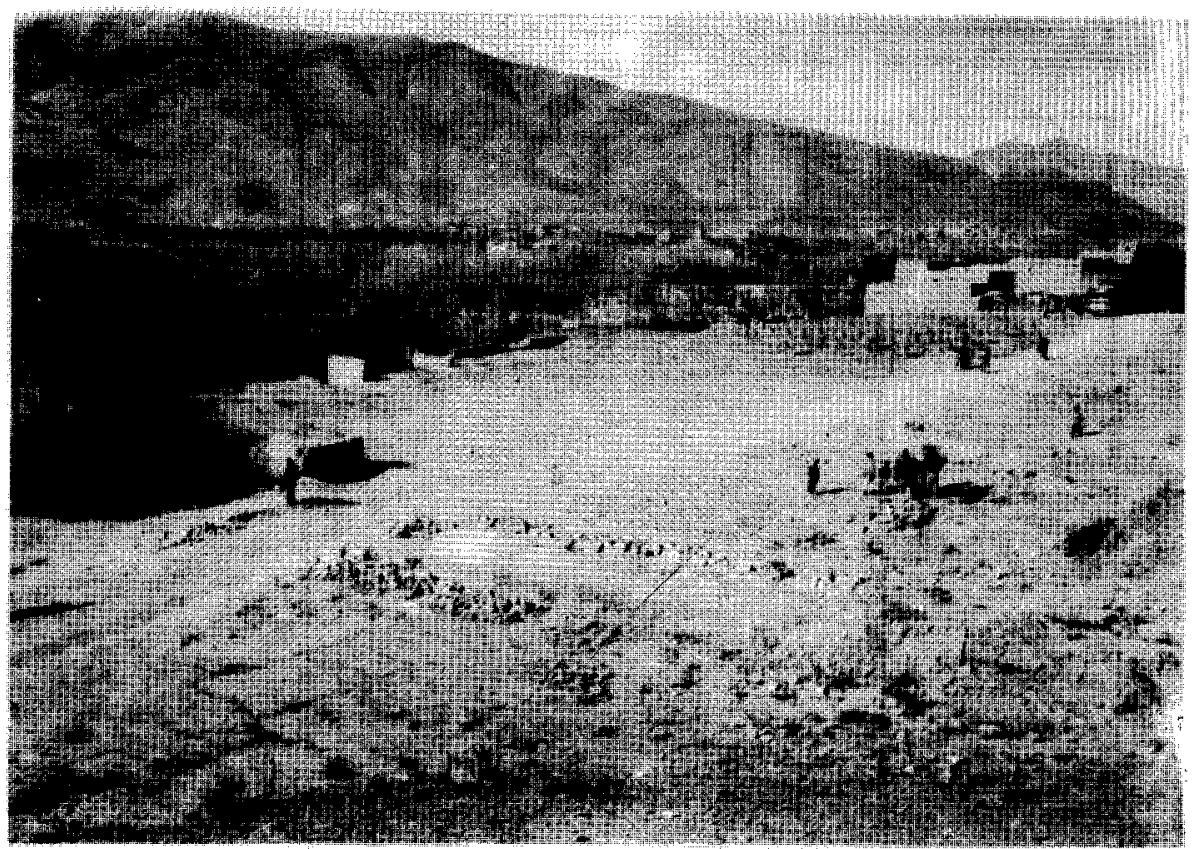

KARIM KHAN SECONDARY SCHOOL:

This secondry school has been perfectly changed to ruin, play game of children and run/stop of vehicles 
START

Reconstruction/Rehabilitation

Programme

Survey of Schools in Chack

Wardak Province

A three member team consigting: Abdul Raqeeb (engineer), Abdul Faheem (engineer), Saduddin (Architect) was sent to Chach district of Wardak province. Through their migyion of 28 days the sketches and photos of the following schools were prepared:

NAME OF

VILLAGE

DISTRICT

SCHOOL

1. Ghardana Masjed

Secondary School

Bayanan

Chuck

2. Araban High School

Araban

"

3. Abkazar

Secondary School

Manjar-Khail

"

4. Ghazi Gul Ahmad

Bahrana

11

Khan Secondary School

5. Nimpai-Qul

Secondary School

Nimpai-Qul

"

6. Tangi Sayeedan

Secondary School

Tangi Sayeedan

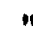

7. Jelga Secondry School

Babak

8. Bamby high school

Chack

1

9. Toap secondry school Tope

Sayed Abad

10. Shaikh Abad Secondry school

Shaikh Abad

11

11. Karim Khan Secondry School

Dawlat Khail

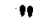

12. Joe Zareen Primary School

Joe Zareen

" 


\section{BHELIER FORM}

\section{START}

Province Wxardak District lhak, Sayed Ábud'

\begin{tabular}{|c|c|c|c|c|c|c|c|c|c|c|c|c|c|c|c|}
\hline \multirow[b]{3}{*}{ No } & \multicolumn{4}{|l|}{ Schools } & \multirow{3}{*}{ 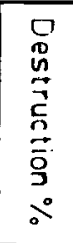 } & \multicolumn{9}{|c|}{ Type of construction materials } & \multirow{3}{*}{$\begin{array}{l}00 \\
0 \\
3 \\
0 \\
\square \\
x \\
n\end{array}$} \\
\hline & \multirow[b]{2}{*}{ Name } & \multirow[t]{2}{*}{  } & \multirow{2}{*}{$\begin{array}{|ll|}\begin{array}{c}n \\
0\end{array} & z \\
n & 0 \\
h & 0 \\
\vdots & 0 \\
0 & \\
3 & \\
\end{array}$} & \multirow[t]{2}{*}{$\begin{array}{l}0 \\
\stackrel{0}{3} \\
\vdots \\
\vdots\end{array}$} & & \multirow[t]{2}{*}{$\begin{array}{l}\pi \\
\stackrel{1}{\circ} \\
0\end{array}$} & \multirow[t]{2}{*}{$\underset{\underline{o}}{\underline{\underline{g}}}$} & \multirow[t]{2}{*}{$\frac{n}{0}$} & \multicolumn{3}{|c|}{ Size of windows } & \multicolumn{3}{|c|}{ Size of doors } & \\
\hline & & & & & & & & & $w$ & $\mathrm{H}$ & No. & w & $\mathrm{H}$ & No. & \\
\hline 1 & $\begin{array}{l}\text { Groidane Masjed. } \\
\text { Secondarr school }\end{array}$ & 8 & 10 & $\begin{array}{l}\text { Peachen } \\
\text { room }\end{array}$ & 85 & & Muad wall & $\begin{array}{l}\text { Soiled } \\
\text { Ground } \\
\end{array}$ & $\begin{array}{l}175 \\
175 \\
\end{array}$ & $\begin{array}{l}110 \\
150 \\
\end{array}$ & $\begin{array}{c}2 \\
17 \\
\end{array}$ & 100 & 200 & 10 & \\
\hline 2 & Aiaban high school & 12 & & . & 100 & & 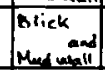 & 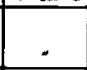 & & & & & & & \\
\hline 3 & Attiazar Secondary schaci & 8 & 10 & $=$ & 95 & & Mad wall & . & 180 & & 12. & $\begin{array}{l}100 \\
200\end{array}$ & & $\begin{array}{l}7 \\
2\end{array}$ & \\
\hline 4 & Ilaikpail'sexi reesudary schoul & 8 & 10 & & 90 & & Stane & . & $\begin{array}{c}160 \\
150 \\
220 \\
\end{array}$ & $\begin{array}{r}120 \\
120 \\
120\end{array}$ & 2 & $\begin{array}{r}100 \\
8 \\
9\end{array}$ & $\begin{array}{l}153 \\
160 \\
117 \\
170\end{array}$ & 1 & \\
\hline 5 & $\begin{array}{l}\text { Shari Ga! Anmad Khan } \\
\text { Secondare school }\end{array}$ & 8 & 12 &  & 96 & & Mud wall & $\therefore$ & 170 & 160 & 37 & $\frac{70}{100}$ & $\begin{array}{l}200 \\
240\end{array}$ & $\begin{array}{c}1 \\
3 \\
3\end{array}$ & \\
\hline 6 & $\begin{array}{c}\text { langhre Saypdan } \\
\text { secondalv scheo! }\end{array}$ & 8 & 8 & . & $1 \mathrm{ll}$ & & Mud brich & 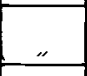 & 165 & 160 & 27 & $\begin{array}{l}100 \\
100 \\
200 \\
\end{array}$ & $\begin{array}{l}200 \\
200 \\
200 \\
\end{array}$ & 9 & \\
\hline 7 & Jelgha, secondaly school & 9 & 16 & $\therefore$ & 86 & & Mud wall & . & & & & & & & \\
\hline 8 & Bumb high school & 12 & 20 & $\begin{array}{l}\text { Poochect } \\
\text { store }\end{array}$ & 90 & & Stome & Conseret & & & & & & & \\
\hline 9 & Dushte treip, secondaty sche & 8 & 8 & 4 & IU & & Mund Brich & $\begin{array}{l}\text { Soiled } \\
\text { Ground }\end{array}$ & & & & & & & \\
\hline 10 & Shaikh Abad, secondary school & 9 & 16 & $\begin{array}{l}\text { beasher: } \\
\text { stous. } \\
\text { Let. }\end{array}$ & 100 & & & $"$ & 200 & & 34 & IIII & 200 & U & \\
\hline 11 & Karim Khan, secondaly schol & 9 & 16 & $"$ & $10 \%$ & & Hilied watill & . & & & & & & & \\
\hline 12 & Joe Zarin, primary school & 6 & 10 & $\begin{array}{c}\text { Teachers } \\
\text { tonm }\end{array}$ & 56 & & & 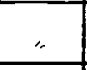 & 95 & 118 & 50 & 180 & 20 & 16 & \\
\hline 13 & & & & & & & & & & & & & & & \\
\hline
\end{tabular}

\section{CHART OF CONSTRUCTION AND LABOUR WAGES}

\begin{tabular}{|c|c|c|c|c|c|c|c|c|c|c|c|c|c|c|c|c|c|c|c|}
\hline \multirow[b]{2}{*}{ No } & \multicolumn{3}{|c|}{ Surveyed Area } & \multicolumn{5}{|c|}{ Cost of materials in (At $\left.f_{a j}\right)$} & \multirow{2}{*}{ 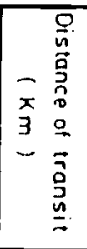 } & \multirow{2}{*}{  } & \multicolumn{3}{|c|}{$\begin{array}{c}\text { Costcf pcrtial } \\
\text { items }\end{array}$} & \multicolumn{3}{|c|}{ Woye per day } & \multirow{2}{*}{ 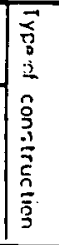 } & \multirow{2}{*}{ 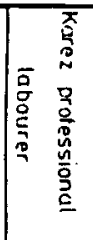 } & \multirow[b]{2}{*}{ rremarks } \\
\hline & Villaye & District & Province & $\frac{T}{0}$ & 号 & 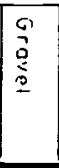 & $\begin{array}{l}n \\
a \\
a\end{array}$ & $\begin{array}{l}n \\
\overrightarrow{5} \\
? \\
0\end{array}$ & & & $\begin{array}{l} \\
\\
\end{array}$ & 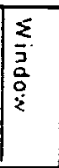 &  & $\begin{array}{l}9 \\
0 \\
0 \\
0 \\
0 \\
0\end{array}$ & 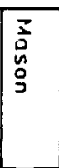 & 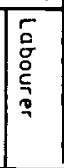 & & & \\
\hline 1 & Byanan & Chak & Wardak & 2000 & . & 3000 & 3000 & 400 & $2 \mathrm{Km}$ & & $8 \times$ & $8 \pi x$ & fum & 2510 & $23 n$ & $\lim$ & & 1000 & \\
\hline 2 & Araban & $\eta$ & . & Not & S.live & yed & & & & & & & & & & & & & \\
\hline 3 & Manjer Khall & . & 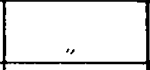 & 20006 & & 300 & $3 a$ & flu & $3 \mathrm{~km}$ & & 0000 & 8000 & 54000 & 154 & 150 & 10 & & 130 & \\
\hline 4 & Nakpai Qool & 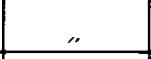 &. & 1800 & & 450 & 150 & 560 & $1 \mathrm{~km}$ & & 8 & $\cos$ & 4000 & 200 & $2 \pi$ & 1000 & & & \\
\hline 5 & Balana & . & 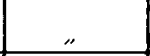 & 1600 & & socic & 400 & 145 & $1 \mathrm{~km}$ & & 8000 & $180 \pi$ & $\$ 0000$ & 2000 & 2000 & $\operatorname{lin} x$ & & & \\
\hline 6 & Tanghee Soyeda & on & 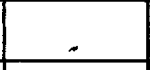 & 10000 & & $35 w$ & $35 k$ & dibl & $1 \mathrm{~km}$ & & on & 8000 & 30,00 & 80 & 800 & $5 a$ & & & \\
\hline 7 & Babak & . & _ & 12000 & & $8 \times 0$ & ouc & $(606)$ & $1 \mathrm{~km}$ & & $\infty$ & 8000 & 60,000 & 200 & 150 & 1000 & & & \\
\hline 8 & lhak &. & . & 20000 & & 7000 & Tue & $18 e_{1}$ & $4 \mathrm{~km}$ & & 800 & 8000 & 60,000 & 2000 & 150 & 100 & & & \\
\hline$y$ & Toop & Sayed Abad & 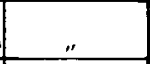 & 22600 & & 2000 & $2 n$ & $35 a_{1}$ & & & eas & 800 & 50000 & 250 & 2000 & 100 & & & \\
\hline 10 & Shaikh Abad & $"$ & - & 18000 & & $25 i c$ & 254 & 3000 & & & 1960 & 10000 & $\infty$ & 250 & 250 & 1000 & & & \\
\hline 11 & Dawlat Khail & " & - & 1500 & & luen & 1600 & 1560 & & & 8000 & 10,00 & 8000 & 1500 & 100 & 600 & & & \\
\hline 12 & Joe Zatin & " & . & 16000 & & 50 & $50 \mathrm{cc}$ & 5000 & & & 10,000 & 1200 & 6000 & 150 & 150 & 600 & & & \\
\hline 13 & & & & & & & & & & & & & & & & & & & \\
\hline 14 & & & & & & & & & & & & & & & & & & & \\
\hline
\end{tabular}






\section{araban high schoor}

This high school was located in Araban village but destructed. Walls of the school is brick and partly solid mud. The team could not received further information due to no permission of the people.

The school was recently repaired by means of Swedish Relief Committee and the students are getting to use it, the pictures attached shows the situation.

The near villages to this school are: Ghani, Shush Khan, Khawja Anghoor Olya, Khooja Anghoor Sofla, Shali and Boom.

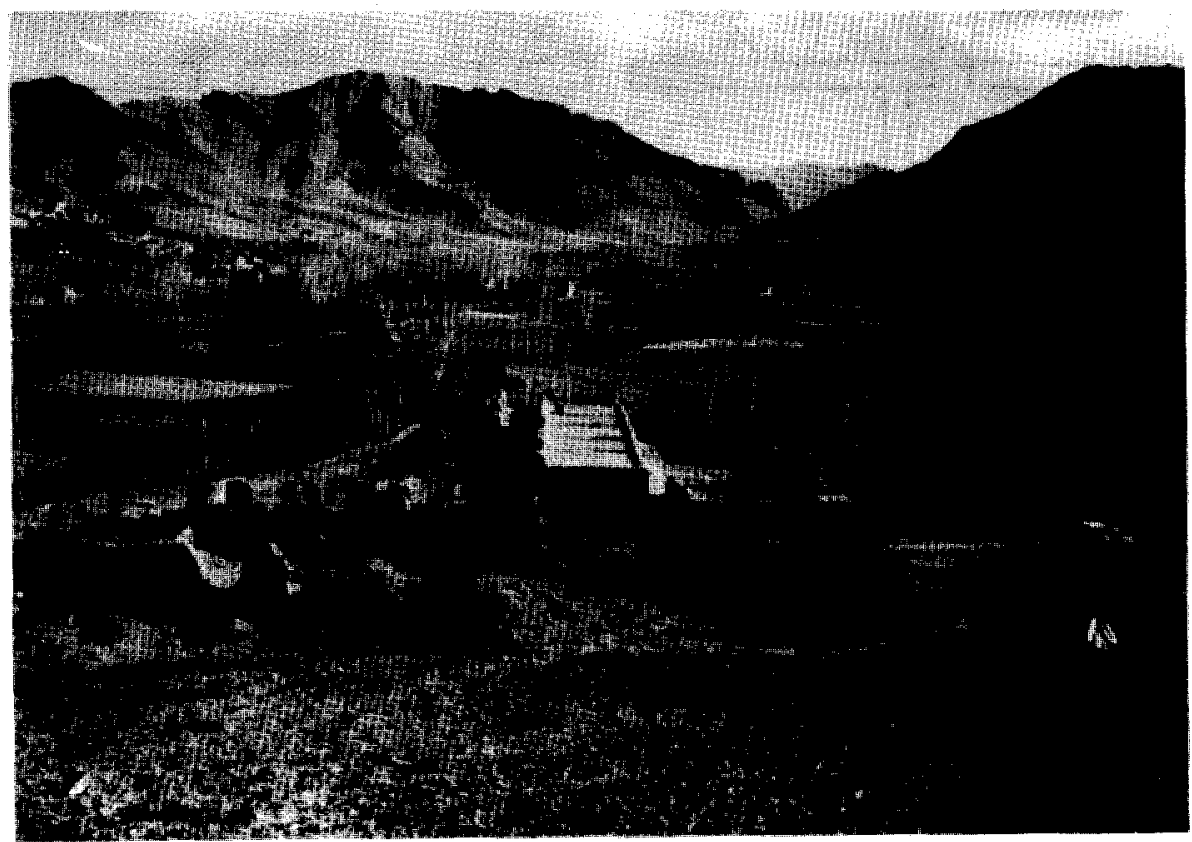



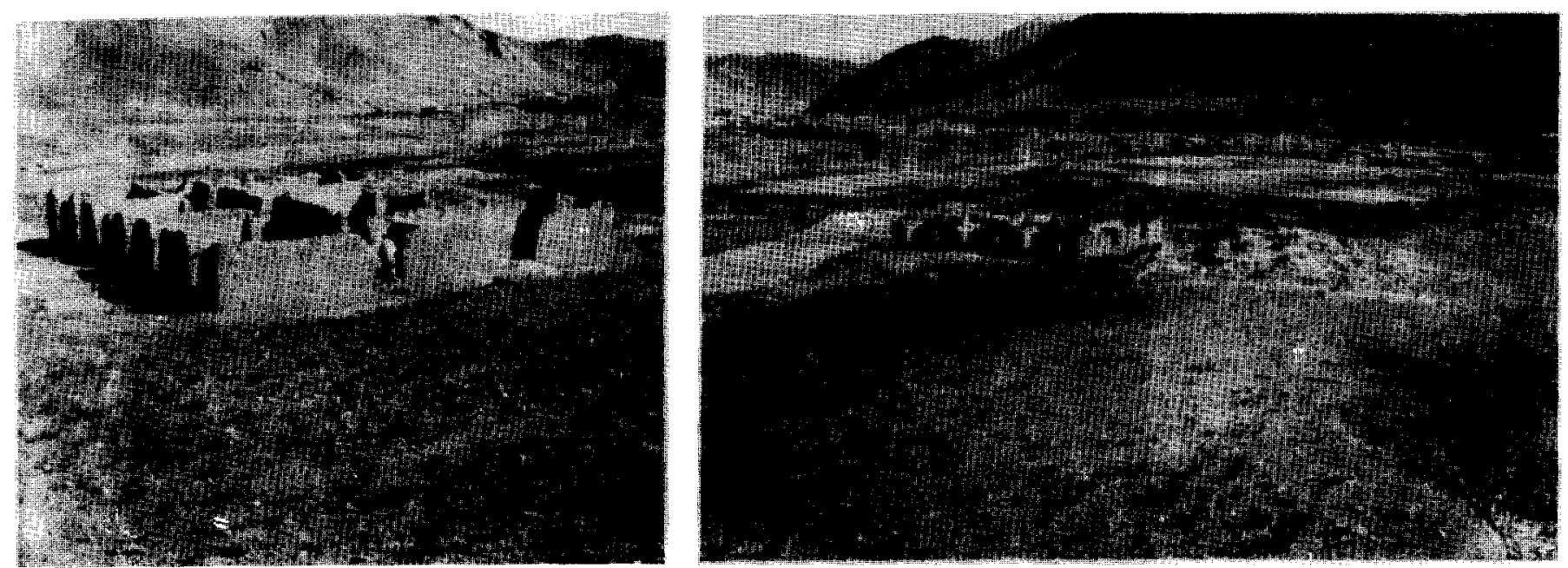

ABKAZAR SECONDARY SCHOOL:

This school is located in Manjar Khail village. Construction of the school is entirely damaged, only solid mud walls remaines. The height of walls are 2 meters but washed-out by rain and is in poor condition.

The students of this school coming from the following villages: Manjar Khail, Chushma, Karkat, Sra Qala, Koan.

The area of this school is 482.38 sqm having 6 class-rooms.






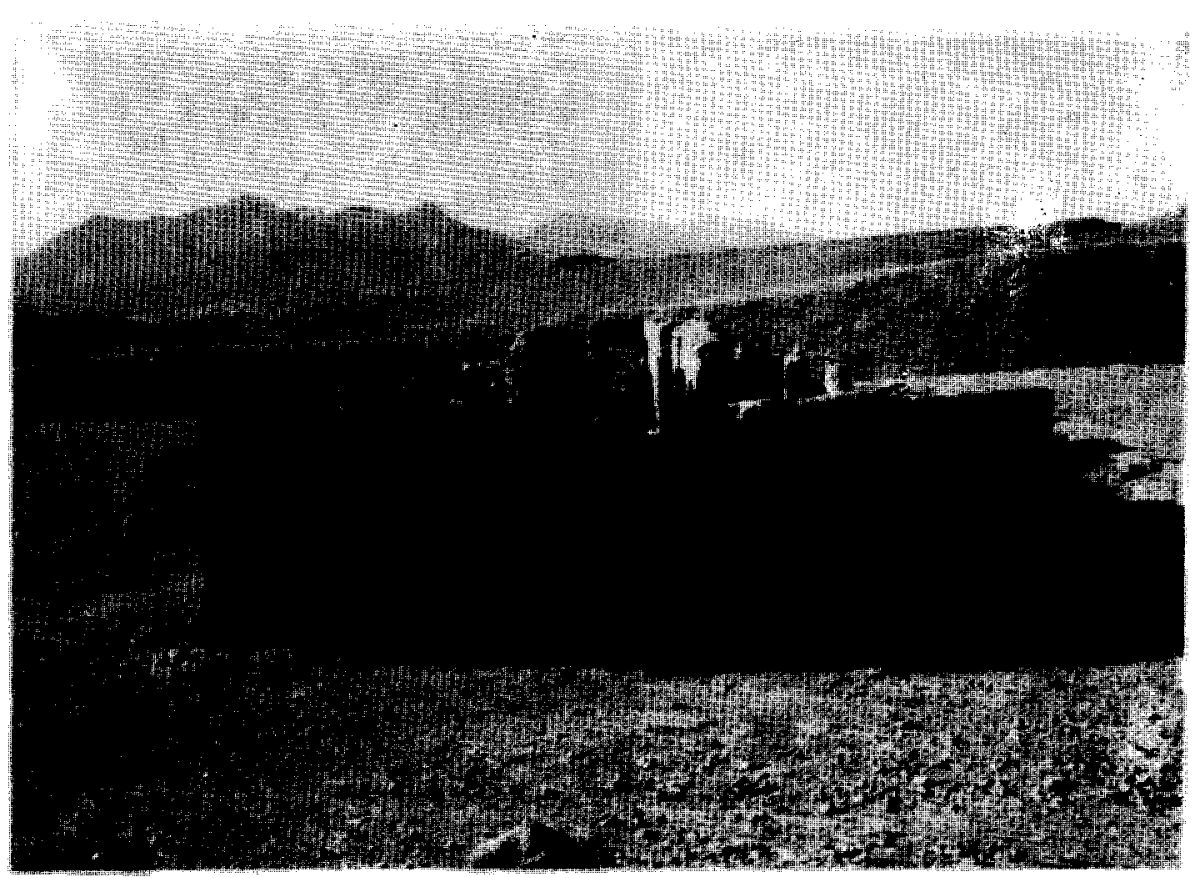

GHAZI GUL AHMAD KHAN SECONDARY SCHOOL:

This mud constructed school is entirely destroyed. It's stone foundation are in proper state having the tolerance of new construction.

The neighboring villages are: Behadana, Hakim Khail, Zaweya, Azad Khail, Goada, Musa Khail, Karana, Sarpoash, Chauni, Robah, Fateh Khail. The school having 12 class-rooms was built in $748.8 \mathrm{sqm}$.

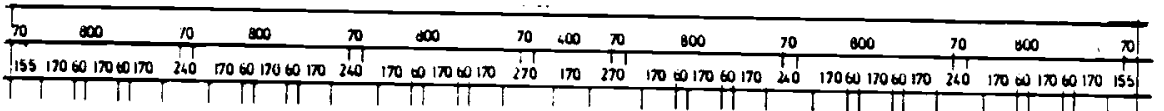

|
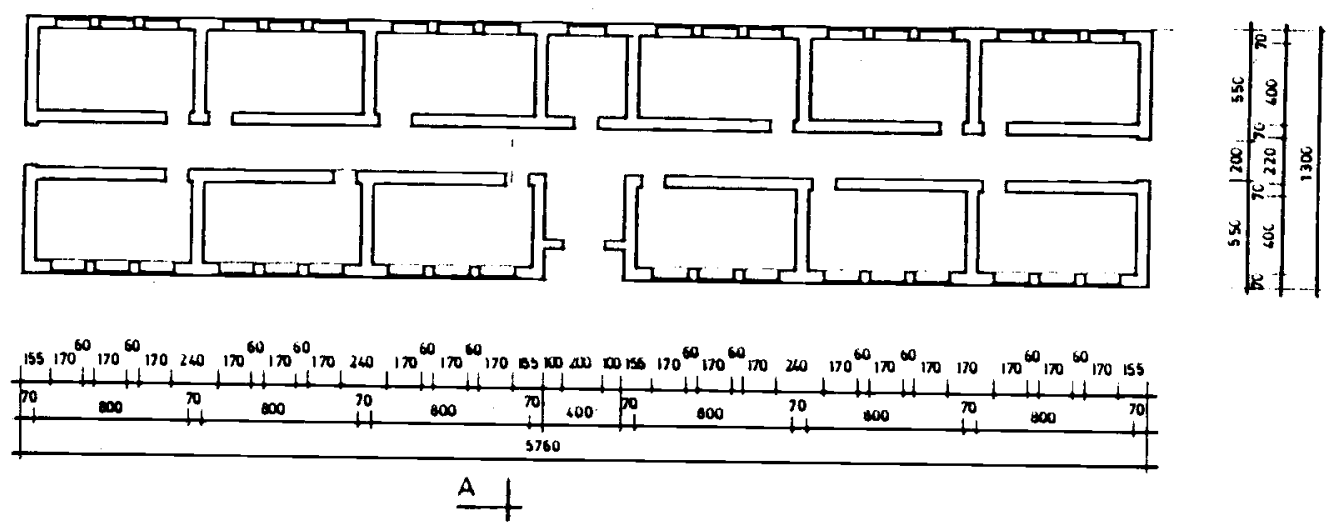

PLAN

seat: 1.200
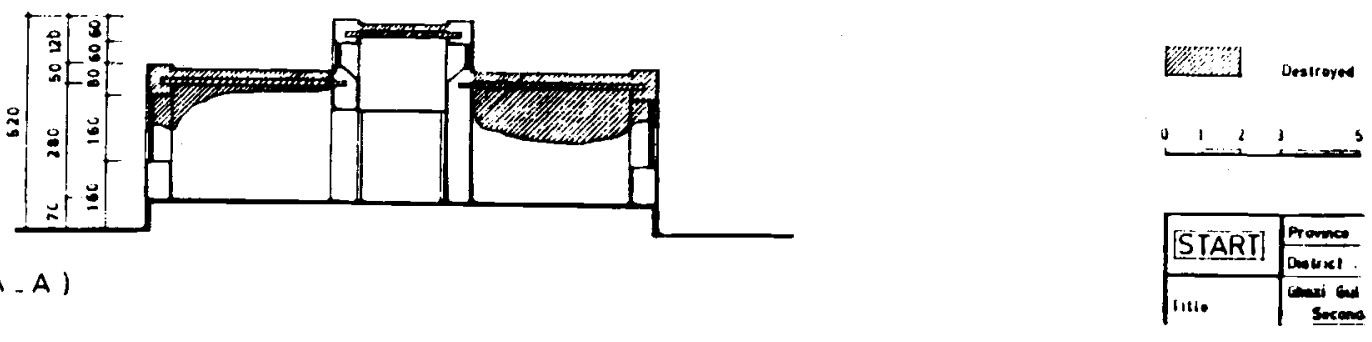

SECTION (A.A) 


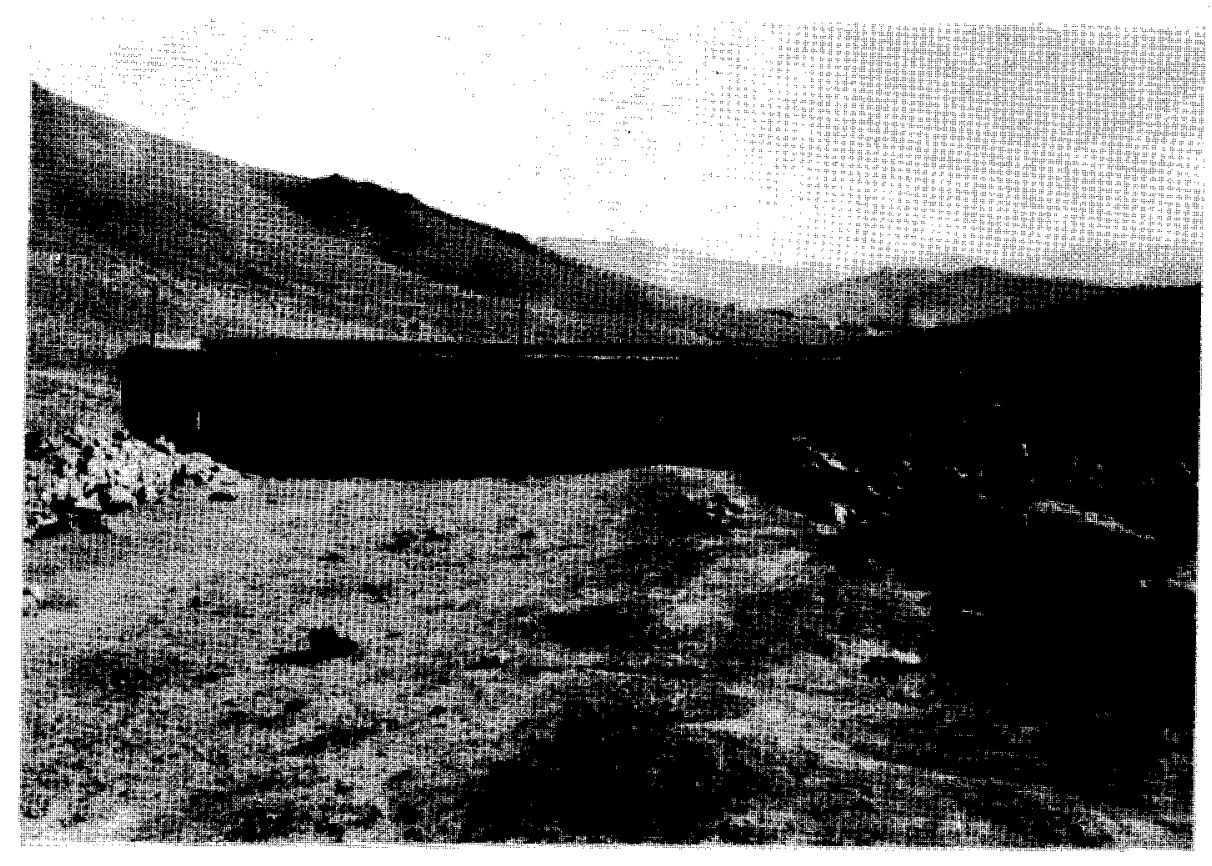

NIMPAI QUL SECONDARY SCHOOL:

This school was built on primitive manner and is still used by religious scholars. Following are the nearest villages to this school: Ghualm, Mahmoud Yawalak, Maroof Khail, Sangh Baba, Kanaiz, Namarak, Cheena, Gul Sind, Char Morda and Qooli Wali.

This school had 11 class-rooms, 8 of them destroyed but 3 remained, its area is $672 \mathrm{sqm}$.

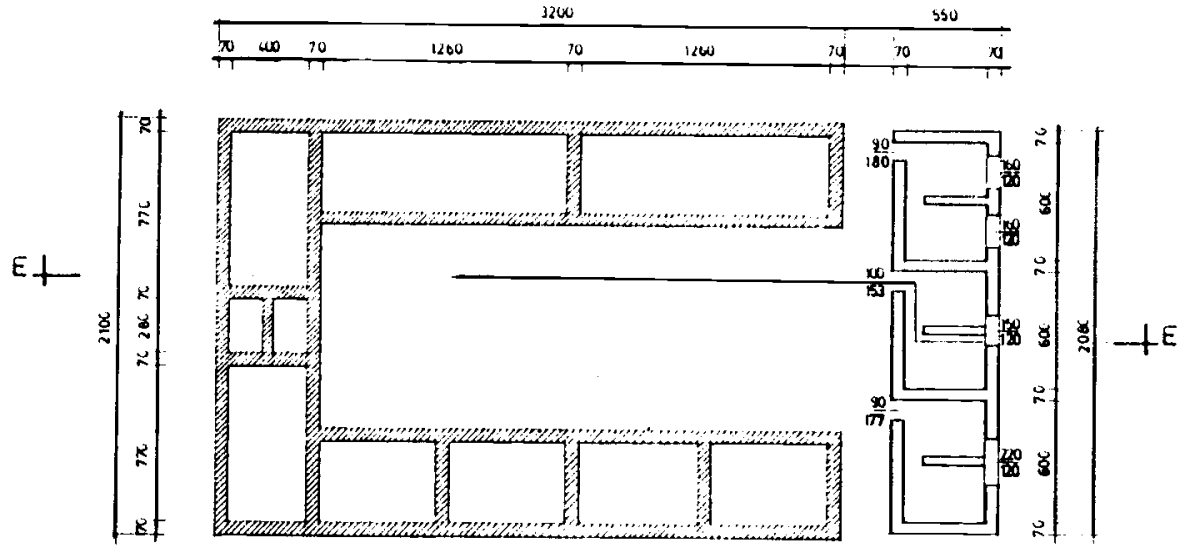

PLAN

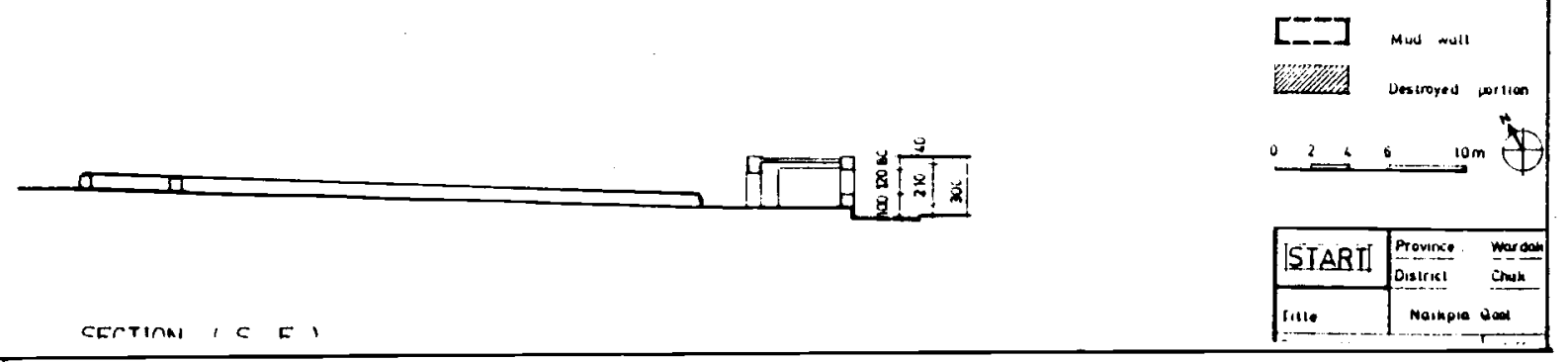




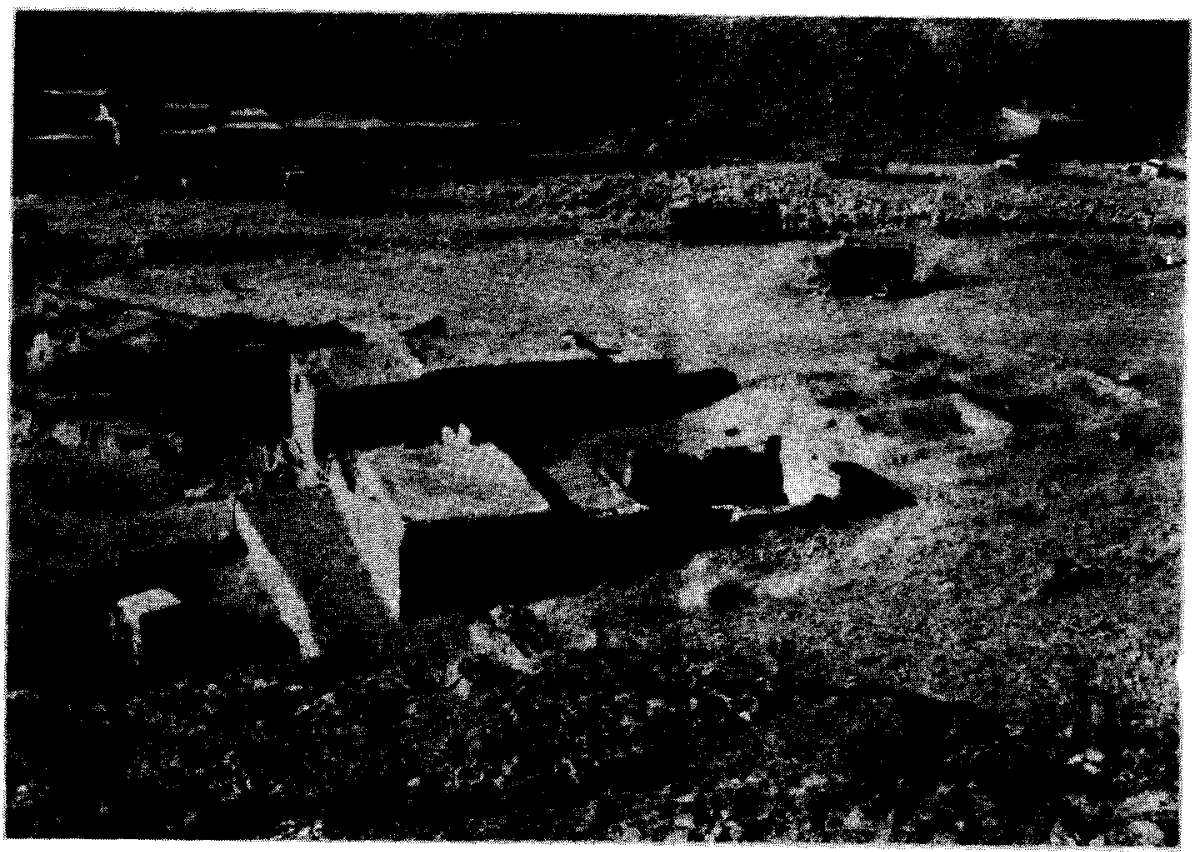

TANGHI SAYEEDAN SECONDARY SCHOOL :

This stone constructed school was destroyed but later changed to private shops by the people. The nearest villages to the school are as follows:

Tanghi Sayeedan, Topaka, Pakar, Sado Khail, Nazok Khail, Gali, Karaiz, Rashi Khail, Koloakh, Seyah Chaghan (upper and lower) Anka, Shahi Khail and Bachgha.

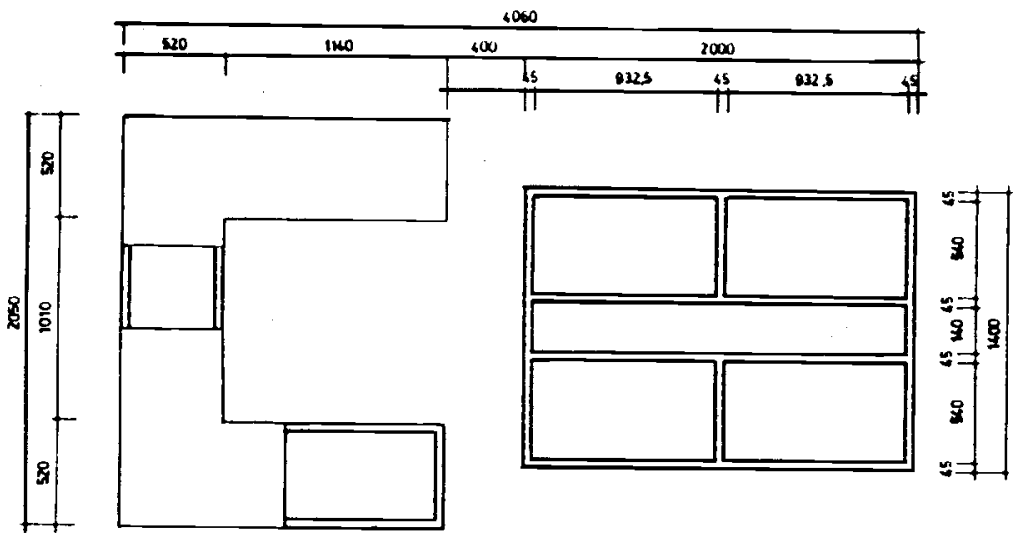

PLAN

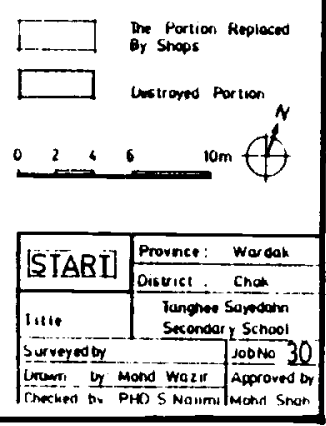




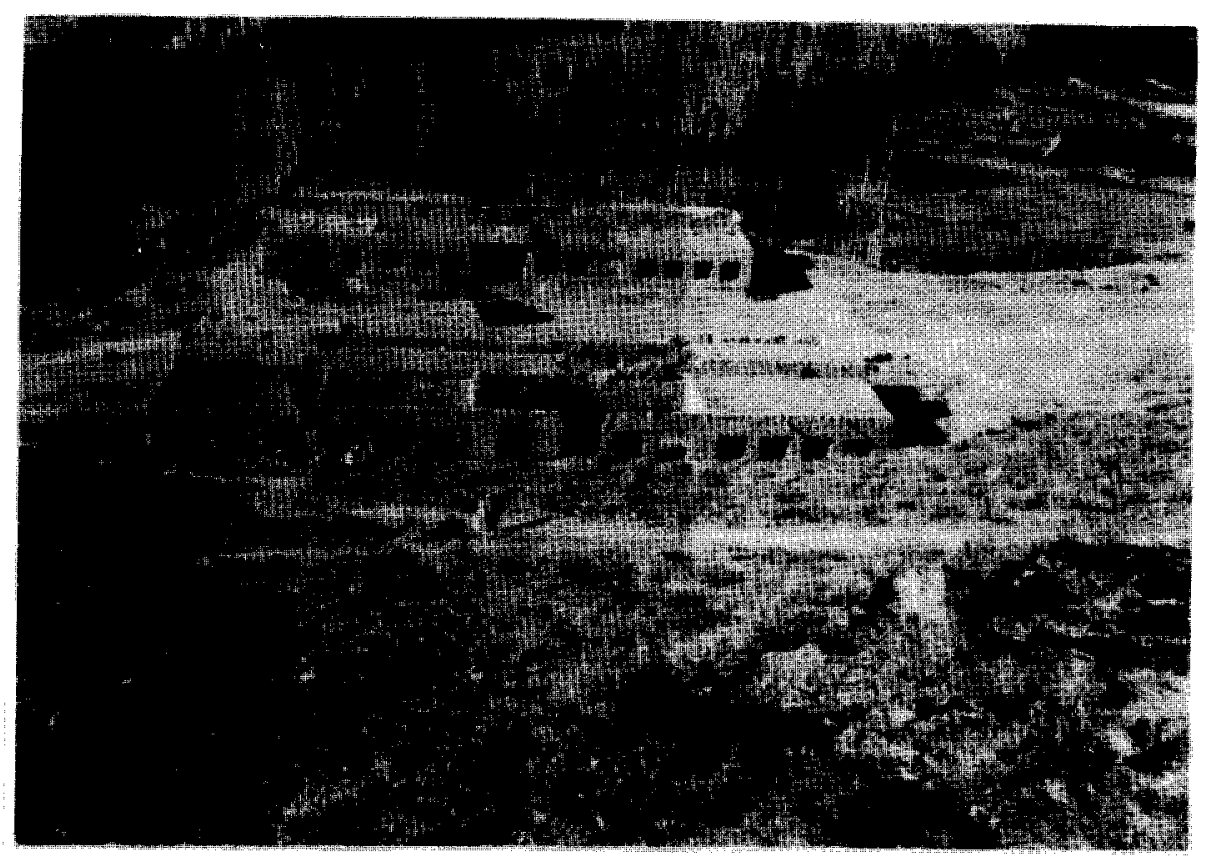

JELAGHA SECONDARY SCHOOL:

This mud 2 blocked school located in a very well location, but not fully destructed like other schools, requires slight amendment. The students from the following villages require to use this school:

Changha (upper and lower changha) Daulat Sha, Shartooghi, Durani, Chatu, Dalan, Nodel, Lashkari and Babak.

Each block contains 8 class rooms with dimension of $612.72 \mathrm{sqm}$.

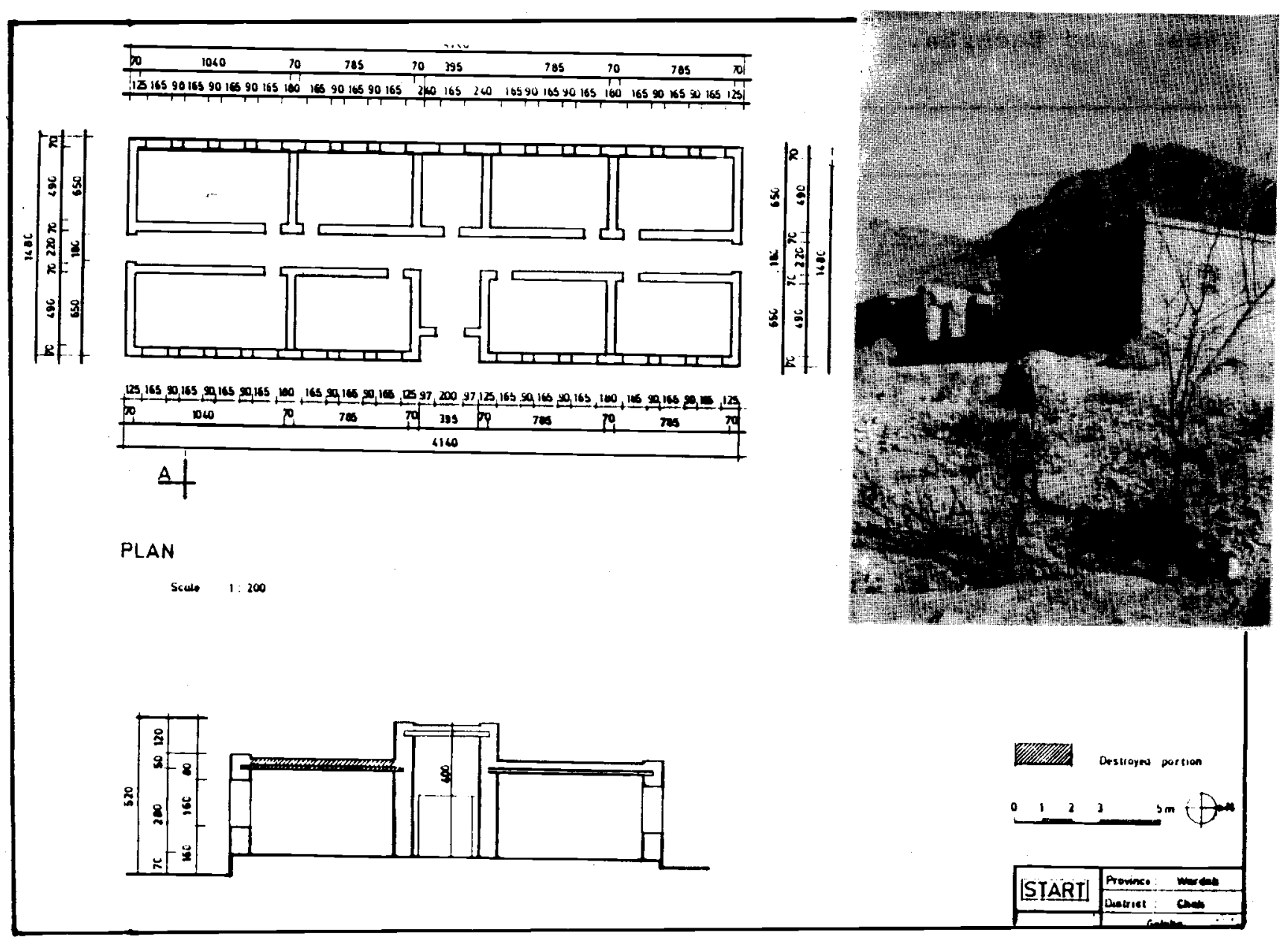




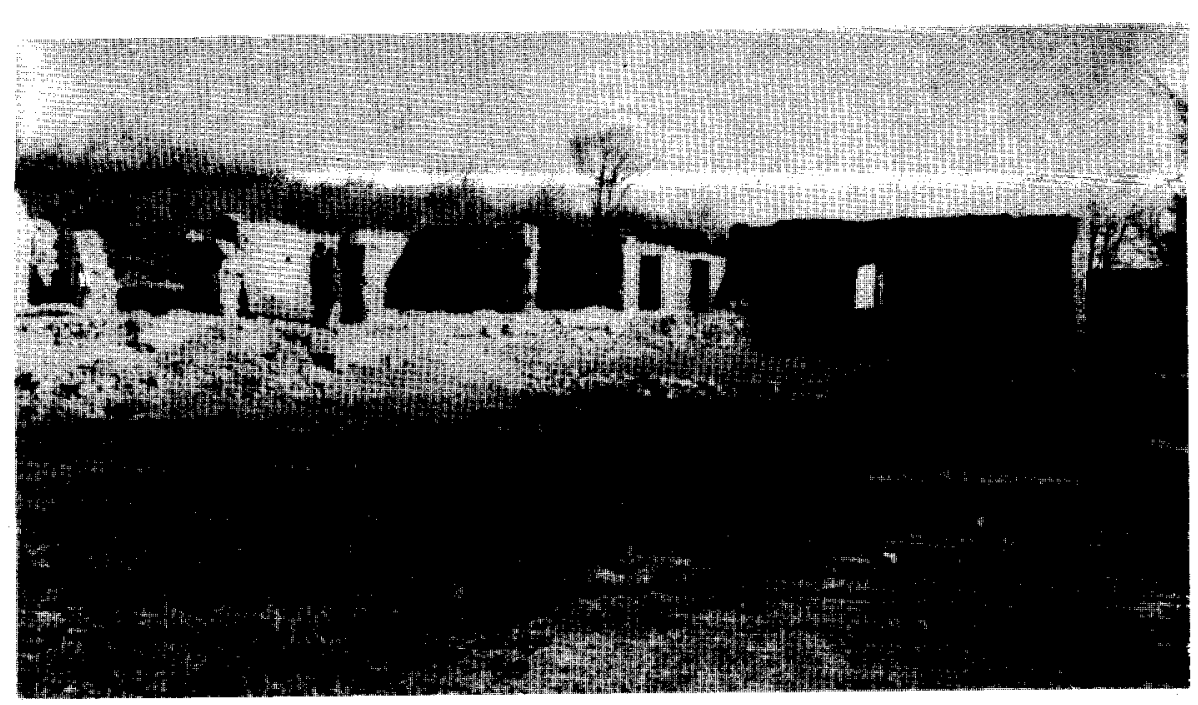

BOMABEY HIGH SCHOOL:

Bombay school in Chack is one of the high-schools in Wardak province with the baccalaureate level graduates.

The destructed feature of the school shows that it was built with stone and concrete but demolished very badly.

Further to the local inhabitants, the students were coming to this school from far distances as bellows: Bombay, Ali Hemmat, Adam Khail, Bik samand, Dauran Khail, Lunghar, Khalili, Ala Khail and Modo villages.

The school was built on $1120.87 \mathrm{spm}$ and had 20 class-rooms.

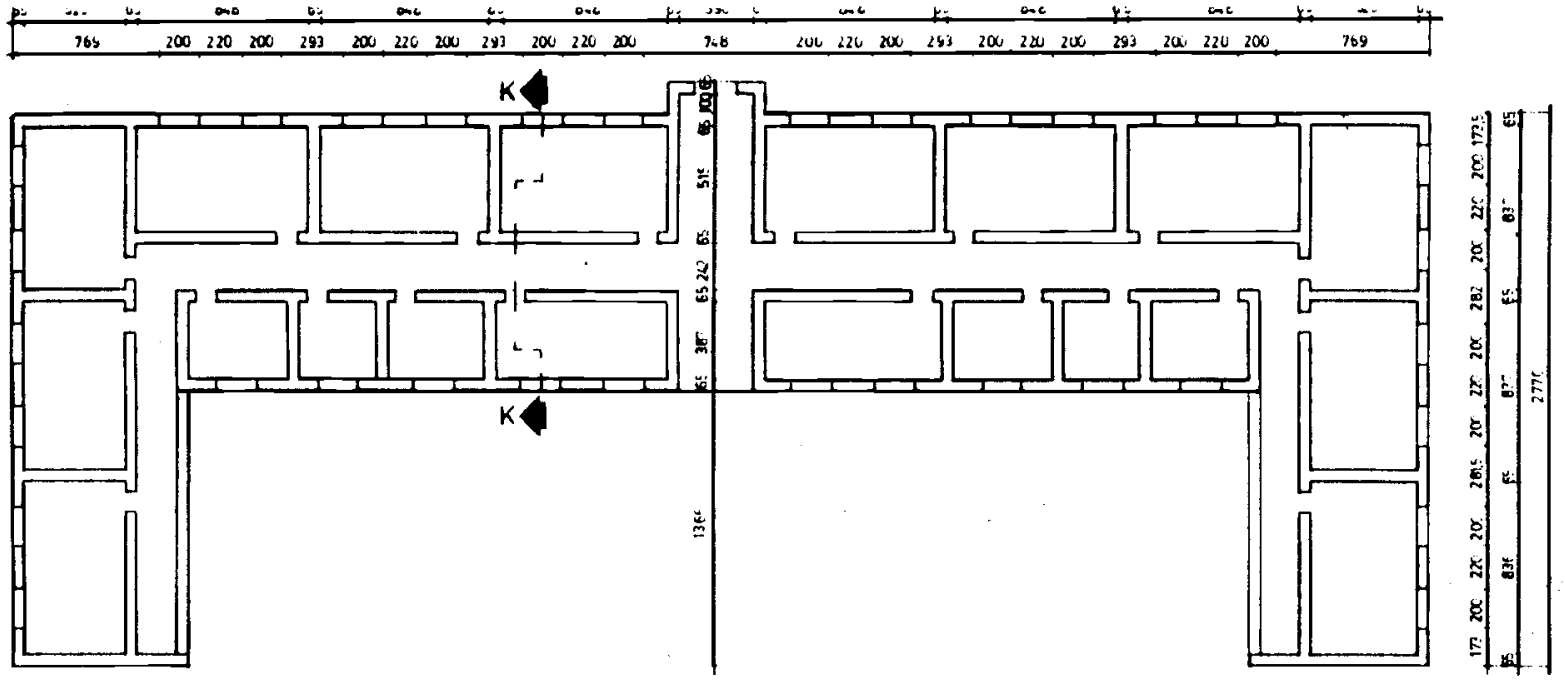

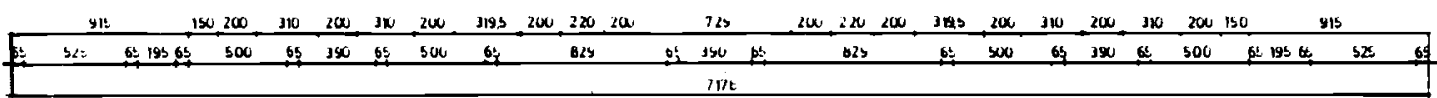

PLAN SCFLLE 1:20,

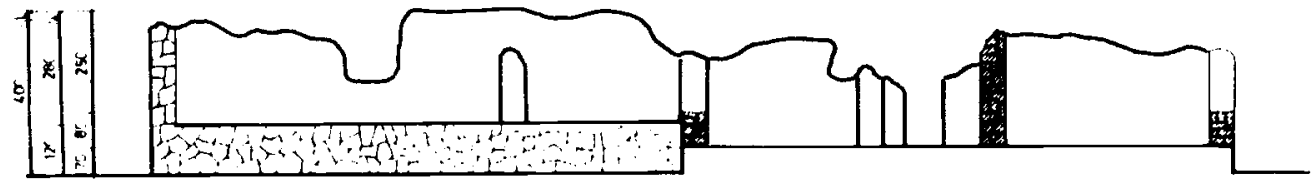

SECTIIN K-K

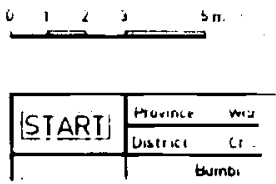


The inventory survey of the prewar school buildings which was carried out by the START team as a pilot project in the context of the rehabilitation of the educational infrastructure and modestly presented in this work shows that both the donor group and the recipients of aid in the sector of education are sincerely interested to now look for proper possibilities of providing school buildings. Some could be provided through efforts of rehabilitating the existing and semi destroyed school buildings while in some cases construction of new building may be needed. In all cases, however, there is a basis that enable the concerned parties to plan, allocate means and fund schools and buildings therefor. It also indicates the agencies working in the education sector should get more closer to each other and through a commonly valued context coordinate the assistance for rehabilitation and promotion of the schools in the liberated parts of Afghanistan.

Afghanistan is so large and so much destroyed that double as much agencies as now operating would not be able to rebuild the country for a decade if not more. The little means and possibilities available would certainly need efficient operation to achieve better results.

Afghanistan Education Committee, a branch of Swedish committee, sponsored this survey which was carried out by the technical staff of START. Reportedly the team did the job in the month of November which is a cold season in Afghanistan and such field works can be difficult. Not having convenient transportation of course also created some difficulties and in result the team was not able to document some of the remote school buildings on further end. Better technical facilities would have resulted in a much improved technical report.

This survey report that 22 prewar schools are presented, 3 high schools, 12 secondary schools, 5 primary schools and two buildings that formerly functioned as schools, in two districts of a province shows the potential of aid absorption in the sector of eduction. This would also mean that newer projects should be designed in order to provide means of complete school educations besides the presently scattered village schools that should be improved and upgraded to a qualified content.

It is recommended that more such surveys should be launched in regards to all prewar school buildings in other provinces and especially where the education is running well today. Similarly other prewar buildings of public use should be documented and evaluated for rehabilitation before one should go into construction of new premisses and functions. This would also require a more integrated study and justification of the rural set up and methods of the rural resettlements or rehabilitation through which comprehensive solutions could be recommended and if possible implemented. 
SCHOOL SURVEY OF WARDAK PROVINCE DEC.1989

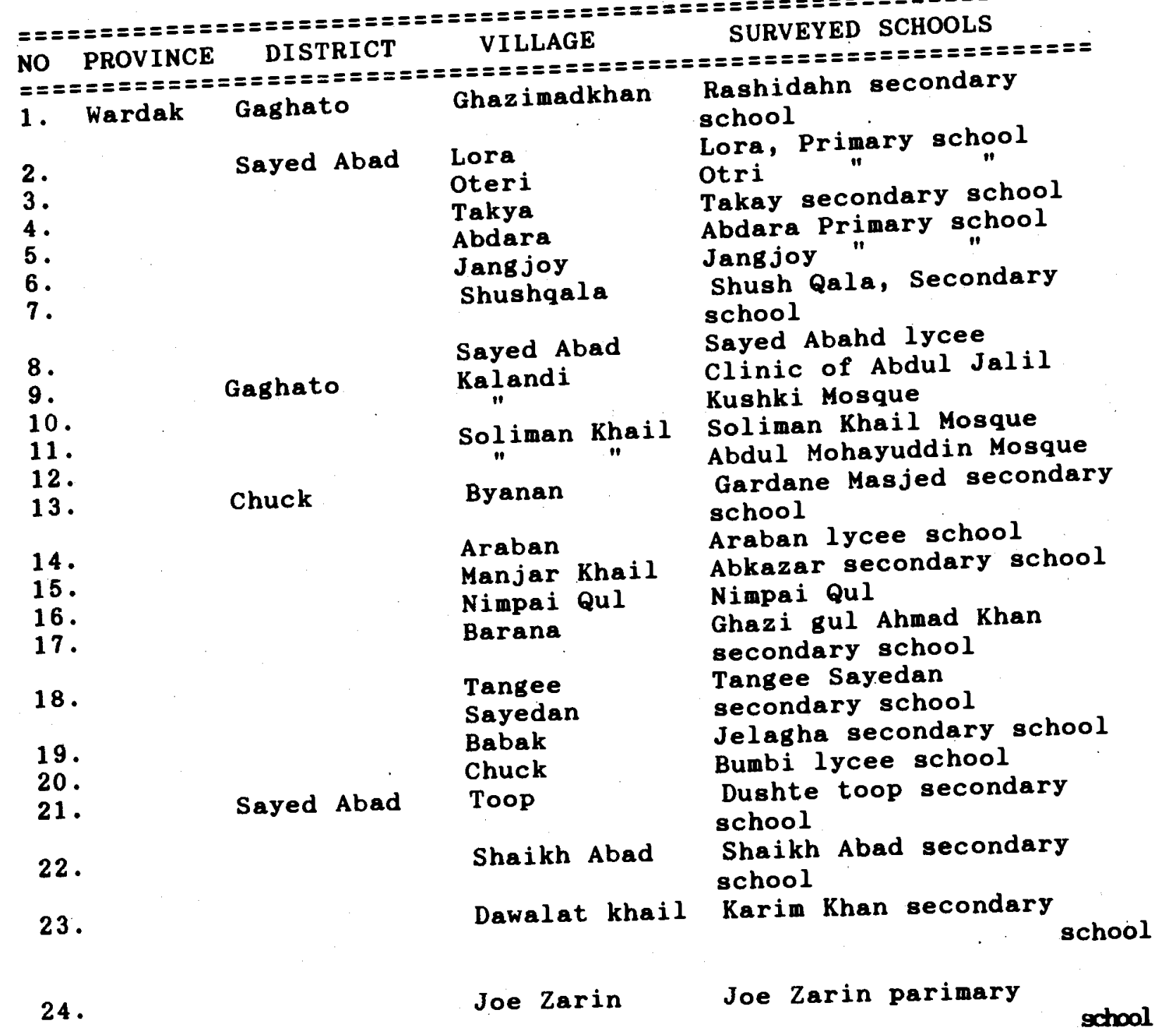


It is also important that the different organizations assisting eductional activities inside Afghanistan should come closer, share informations and experieces and work for a more regionally coordinated educational infrastructure for the future of the country.

There are many organizations talking about and want to be involved in the construction of buildings for schools, and other public buildings, and as it is understood there are funds allocated for the purpose. Although the work seems easy to many but one should not underestimate the task. Whether reconstruction of the prewar school buildings or erecting newer buildings the emphasis should be upon detail analysis of the functions, local building material and ways to improve the traditional mode of construction. Well developed building specifications should be used and reffered to as part of supervision and monitoring activity.

Although there are many qualified construction engineers around but the role of qualified architects in design and planning for reconstruction, rural planning through the context of rehabilitation should not be overlooked.

For developing a positive competition among the technical staff and the NGOs involved in construction and development inside Afghanistan the donnor group is recommended to enforce a process of technical tender and quality competition.

Peshawar

January 1990

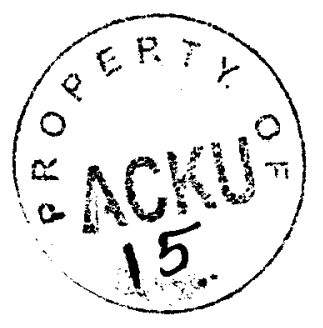




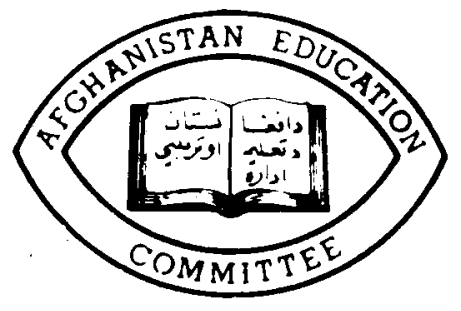

\section{Afghanistan Education Committee} Associated Moith The Swodish Committes



\section{Office Address :}

15.A, GUL MOHAR LANE UNIVERSITY TOWN PESHAWAR - PAKISTAN

\section{Postal Address :}

UNIVERSITY POST OFFICE BOX NO. B76

\section{Telephone: Telex:}

$\$ 1247$ 52365 SCAPK

\section{GRINDLAYS BANK PESHAWAR A/C $1.1313 \quad 50617 \quad 009$ \\ Banker :}

